\title{
Traffic Planning and Major Intersection Re-design of an Existing Four- Armed Intersection at DB road, Coimbatore, India
}

\author{
Elangovan K ${ }^{1}$, Gowtham G ${ }^{2}$, Pranav Srinidhi B ${ }^{3}$, Siva Venkatesh Anand S 4 . \\ ${ }^{1}$ Professor, Department of Civil Engineering, PSG College of Technology, Coimbatore - 641004, Tamil Nadu, India. \\ ${ }^{2}$ PhD student, Department of Civil Engineering, Indian Institute of Technology Kanpur, Kanpur, Uttar Pradesh, India. \\ ORCID: 0000-0001-7272-6503.
}
${ }^{3}$ M.Tech student, Department of Water Resources \& Ocean Engineering (Formerly Applied Mechanics \& Hydraulics), National Institute of Technology Karnataka, Surathkal, Karnataka, India. ORCID: 0000-0001-8553-0884.

${ }^{4}$ Former undergraduate student, Department of Civil Engineering, PSG College of Technology, Coimbatore, Tamil Nadu, India.

\begin{abstract}
This paper suggests the traffic planning through major intersection design of a four-armed existing crossroad in Coimbatore, Tamil Nadu in India. Also, this paper discusses about the design of street elements along the existing road. This article is based on the undergraduate project done by the authors ${ }^{[1]}$.

With the assistance of sitework, the topographic survey is carried out by observing the existing features such as inadequate foot path, misplaced garbage bins on foot path, etc. The necessary data such as pedestrian and parking counts are taken along the DB road. The traffic data are collected by manual method of taking traffic counts of the incoming traffic in all the four roads by each person. Based on the traffic counts the PCU/Hour is calculated for every road and the traffic signal has been redesigned based on IRC: $93-1985^{\text {[2] }}$. The results show redefined traffic signal timings with the design of major intersection and street elements.
\end{abstract}

Keywords: Traffic planning, Topographic survey, Street elements, IRC:93-1985, Traffic signal redesign, Major intersection design, Traffic count.

\section{Highlights:}

- The topographic survey has been carried out around the area to be redesigned and the problems are identified.

- Pedestrian and parking counts have been taken along the relevant road.

- Traffic count has been carried out at the peak hour with the incoming traffic at each arm by observers at each arm of the intersection.

- Right of way has been reassigned for the existing road.

- The street elements have been rectified and the major intersection is designed.

\author{
Abbreviation: \\ BSCL - Bhubaneshwar Smart City Limited \\ BRT - Bus Rapid Transit \\ CCMC - Coimbatore City Municipal Corporation \\ $\mathrm{D}$ - Deceleration rate \\ D.B. road - Diwan Bahadur road \\ EPC - Engineering, Procurement and Construction \\ $\mathrm{G}-$ Green time for the respective phase \\ GI - Galvanised Iron \\ GIS - Geographic Information System \\ INR - Indian Rupee \\ Int. - Intersection \\ IRC - Indian Road Congress \\ IS - Indian Standards
}

ITDP - Institute for Transportation and Development Policy

$\mathrm{L}$ - Average length of the vehicle

LOS - Level of Service

$\mathrm{L}_{\mathrm{a}}$ - Redefined cycle length

$\mathrm{L}_{\mathrm{e}}-$ Available effective time for the respective phase

$\mathrm{L}_{\mathrm{m}}$ - Movement lost time for the respective phase

$\mathrm{L}_{0}$ - Cycle length for the respective phase

$\mathrm{L}_{\mathrm{r}}-\mathrm{All}$ red time for the respective phase

$\mathrm{L}_{\mathrm{t}}$ - Total lost time

MRTS - Mass Rapid Transit System

MS - Mild Steel

MSW - Municipal Solid Waste

MV - Motorized Vehicle 
NA - Not available

NMT - Non-Motorized Transport

PCU - Passenger Car Units

PCU/hr - Passenger Car Units per hour

PHV - Passenger Hour Volume

$q$ - Peak traffic flow of the particular phase in PCU/hr

RCC - Reinforced Cement Concrete

$\operatorname{Rd}-\operatorname{Road}$

RoW - Right of Way

R.S. Puram - Rathina Sabapathi Puram

$\mathrm{s}-$ Saturation flow in PCU/hr

sq. - Square

$\mathrm{T}_{\mathrm{a}}-$ Amber time

$\mathrm{T}_{\mathrm{p}}-$ Pedestrian crossing time

$\mathrm{T}_{\mathrm{r}}-$ Reaction time

TRIPP - Transportation Research and Injury Prevention Programme

T.V. Swamy road - Thiru Venkata Swamy road

$\mathrm{V}-$ Velocity of the vehicle

$\mathrm{W}-$ Width of the road

$\mathrm{Y}$ - Total flow ratio of critical movements

$\mathrm{Y}_{\mathrm{i}}$ - Flow ratio of critical movements for the respective phase

\section{INTRODUCTION}

This study mainly focusses on re-designing an urban street intersection to provide adequate amenities for pedestrians and cyclists by introducing good quality footpaths and cycle tracks, good on-street parking practices, exclusive pedestrian crossing by ensuring their safety.

The study area is Coimbatore Municipal Corporation in Coimbatore district of Tamil Nadu in India. Located on the banks of the Noyyal river surrounded by the Western Ghats, it is the second largest city in the state after Chennai and $16^{\text {th }}$ largest urban agglomeration in India.

The area under study for which a smart road (Model road) has been proposed is D.B. road and T.V. Swamy road located at R.S. Puram, Coimbatore (Refer figure 1 for photograph of the intersection). D.B.road is one of the important roads in R.S. Puram area apart from T.V. Swamy road and Mettupalayam road. D.B. road connects Sukrawarpet street, Gandhi Park, Coimbatore and Cowley Brown road, Coimbatore. D.B. road is parallel to Thadagam road and Mettupalayam road, Coimbatore. The location of D.B. Road is $11^{\circ} 00^{\prime} 26.9^{\prime \prime} \mathrm{N}$, $76^{\circ} 57^{\prime} 03.3^{\prime \prime} \mathrm{E}$.

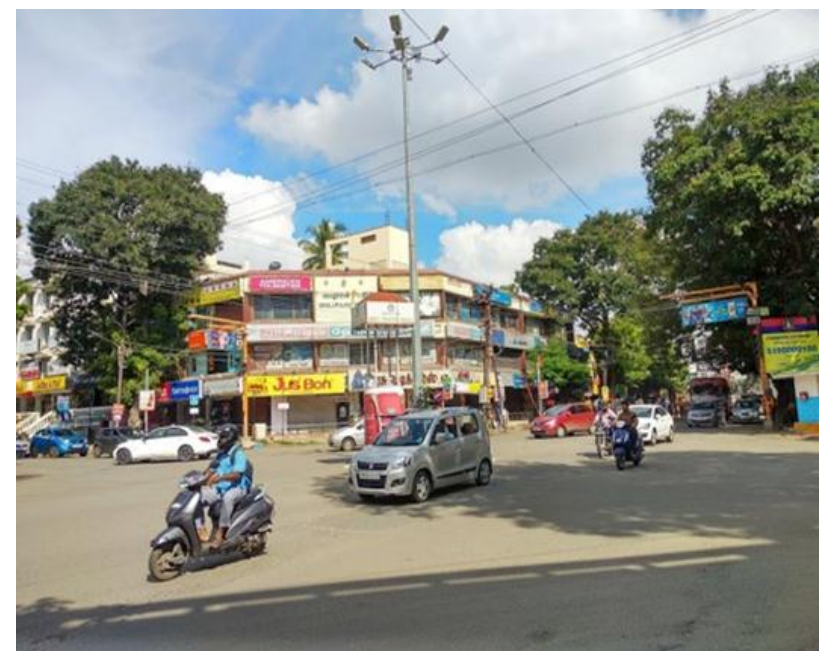

Figure 1: The photograph of D.B. road and T.V. Swamy road (four-armed) intersection.

- The prevailing foot path has inadequate width for the prevailing pedestrian traffic. Provisions for street furniture, common dustbin, public toilets, etc., were not provided. The maintenance of the footpath is poor and, in some places, it is worse too. The footpath laid has not incorporated the principle that, "The footpath should be universally accessible". The continuity of footpath is not maintained and there are no ramps for entering in to private properties. The footpath stops abruptly at intersections and at entrances of the private properties. The above challenges cause discomfort to pedestrians and they avoid using footpath.

- Cycle tracks were not included in the street design and hence D.B. road has no cycle tracks. This makes the cyclists to use the motorized vehicle lane and may be prone to accidents.

- The parking facilities in D.B. road is not clearly marked, though it may be done in some places. Due to this there exists angular parking for both car and two-wheelers. Although angular parking may be acceptable for twowheelers, for cars it is not desirable as it would occupy a considerable width in the carriage way. This would reduce the carriage way width and would cause congestion.

- At the intersection of D.B. road and T.V. Swamy road, the prevailing traffic signal causes excess delays to the commuters. Zebra crossings for the passengers were also not available at intersection. This leads to conflicts between the vehicles and pedestrians. Parking of vehicles near the signals at each arm is not being restricted. This also causes a discomfort to motorized vehicle riders.

- There was no proper pedestrian crossing signage at the intersection.

- At the intersections of west Arokiyasamy road and Ramachandra road with D.B. road, the pedestrian-vehicle conflict was high and there was no traffic calming measures.

- Above all, in order to reduce the traffic congestion prevailing in the city due to personalized motor transport and to reduce the emission levels of vehicles, a street/road that have good facilities provided for the non-motorized traffic, including pedestrians is required. As per "Coimbatore Street Design and Management Policy" by 
ITDP [3] for Coimbatore City Municipal Corporation, in 2014, the number of citizens using bicycles and walking as a mode of transport in Coimbatore (for short/ long trips) is only $23 \%$. If the same condition prevails, it is stated that by 2031 , the above number would reduce to $19 \%$. The percentage of people using buses as their transport would reduce from $33 \%$ in 2014 to $16 \%$ by 2031 . On the other hand, the number of personalized motor transport would increase from $34 \%$ to $53 \%$ by 2031 . If Coimbatore invests in NMT facilities and public transport the trends can be reversed.

All the above key issues at D.B. road, Coimbatore are the basic needs upon which this study was carried out.

\section{LITERATURE REVIEW}

The past studies show the various aspects in smart planning of the street elements and traffic calming measures. Some of these studies are given as below;

India Smart City Mission, 2017 established the 'Smart Janpath' in Bhubaneswar Smart city Limited ${ }^{[4]}$

This study highlights the main achievements of the smart Janpath project which was implemented at Bhubaneswar city of Odisha province in India by the BSCL in the year 2017. The problem identified along the path of stretch of the road during the initial survey were encroachment by public utilities, unregulated parking, unused space and unorganised street vendors. The proposed elements such as dedicated corridor for pedestrians and cyclists, enhanced footpath by adding frontage zone, plantation zone, cycle tracks and maintaining a constant carriageway width which in turn proved to be beneficiary to the citizens.

Gupta Das, et.al., 2004 studied the 'Effect of bus stops on capacity of urban roads - A case study of Delhi urban area' 55

This article gives an insight to the effects caused by the various positions of bus stops on urban roads in the Delhi urban area in India. The effects of having under managed bus stops in Delhi area is also mentioned in the article. It states that, queuing up of buses at the bus stops reduces the lane width of the carriageway and it causes considerable delay in the movement of vehicles. This study was carried out through video recording system, recording the flow characteristics in front of selected bus stops. From the analysis of various selective bus tops, the conclusions explained that the capacity of the carriage way reduces immaterial of the type of bus stop; smooth merging and diverging measures would be able to reduce this loss along with proper enforcement measures.

\section{Muror, et.al., 2013 studied the 'Planning for pedestrians: A wav out of traffic congestion ${ }^{5[6]}$}

The study focusses in the negative aspects of street and urban planning which is usually prevalent. Romanian cities were considered for the study. The problem defined in the study is the increasing personal mobility which leads to more private vehicles. This obviously leads to increase in demand for parking spaces. Congestion levels in streets increases and hence there will be increase in the capacity of the road by increasing its width. This study suggests that in order to reduce the traffic congestion in the city, encouraging public transport and planning for cycling and walking facilities would be a better solution. It was also stated that amenities provided within the reach represents the key to enhance the pedestrian and NMT movement.

\section{Gonzalo-Orden, et.al., 2016 studied the 'Traffic calming measures and their effect on variation of speed, [7]}

The article mainly focuses on analysing the effectiveness of various traffic calming measures in reducing the speed of the vehicles. In this study measurements of speeds of the vehicles were taken in the traffic calmed streets of Burges which is a medium sized city in north central part of Spain. Important conclusions derived from the study were: Best traffic calming measure in terms of effectiveness in speed reduction are raised crossing (cross-walks) and lane narrowing. Speed warning signs work effectively only when some traffic calming measure has been provided before and after them. At the intersections, traffic signals prove to be effective traffic calming element. It was also concluded that, a single traffic calming measure would not be effective and a good combination of such measures are required.

\section{Advani, et.al., 2017 studied the 'Methodology for evaluating walking facilities based on the types of obstructions observed on the footpath of Indian roads, ${ }^{[8]}$}

This study focuses on the available hindrances to the pedestrian movement in the footpath. Data collection on streets was made with the help of continuously recording video camera for the specified stretch of road. For every metre of street, the following were noted - availability of footpath, parked vehicles, trees, poles, gate openings, personal gardening, potholes, garbage, mud, hawkers, etc. All the above obstructions were classified in to three groups based on how easy or difficult to remove them. Group 1 consist of obstructions that are easy to remove like garbage, etc. Group 2 consists of parked vehicles, hawkers, etc. Group 3 consist of constructed urinals, other multi utility facilities, etc. Finally, the study concluded that the obstruction caused by parked vehicles and hawkers as the most affecting obstruction. It also concluded that due to presence of frequent ups and downs in the footpath, the pedestrians find it difficult to travel on it.

\section{METHODOLOGY}

\section{Topographic survey via observation}

Figure 2 indicates the map showing the phase detail of outgoing traffic from each arm. Phase 1, 2, 3 and 4 represents the traffic flow from West T.V. Swamy road, North D.B. road, East T.V. Swamy road and South D.B. road respectively.

This survey determines the location of natural and man-made physical features, such as buildings, immovable street furniture etc. Landscape features such as the location, spread and value of existing trees, shrubs and green areas are also noted. This survey also locates all important features on the site and records three dimensional coordinates, either absolute or in reference 
to traverse points. The location of the objects such as compound wall (including private property gate location and widths), building names for reference, Manholes, drains, pits etc. Trees (differentiated by circumference) must be noted in this survey.

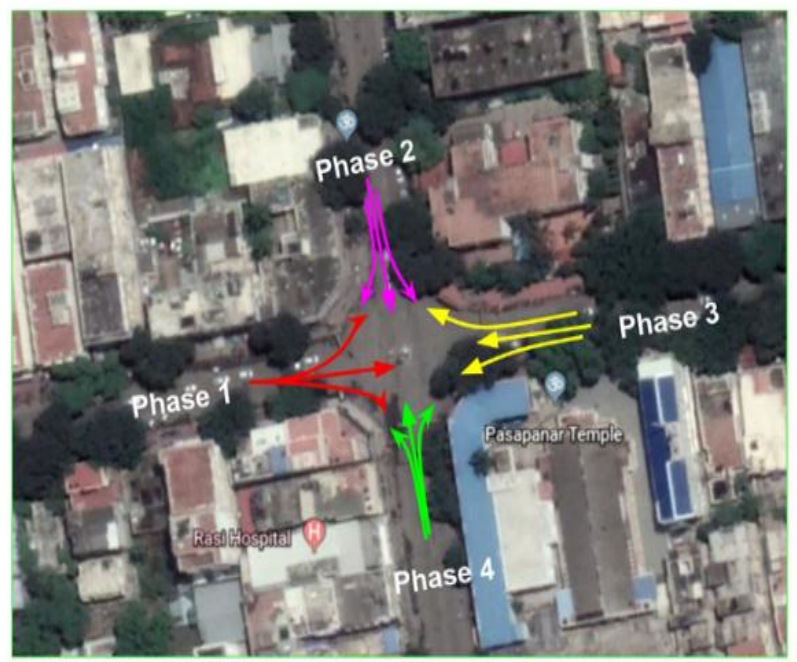

Figure 2: The traffic phase detail of the intersection

- From the observation conducted on the Southern side of D.B. road, R.S. Puram, Coimbatore, it was identified that from the intersection of D.B. road and Sundaram street to Tanjore art gallery, D.B. road, the footpath was used as a dumpsite for dumping MSWs (Refer figure 3). This creates discomfort for the passengers to use the footpath and they were using the MV lane only. Also, the placing of waste collection dustbin is inappropriate and its poor maintenance may lead to sanitary issues and other health issues to the citizens.

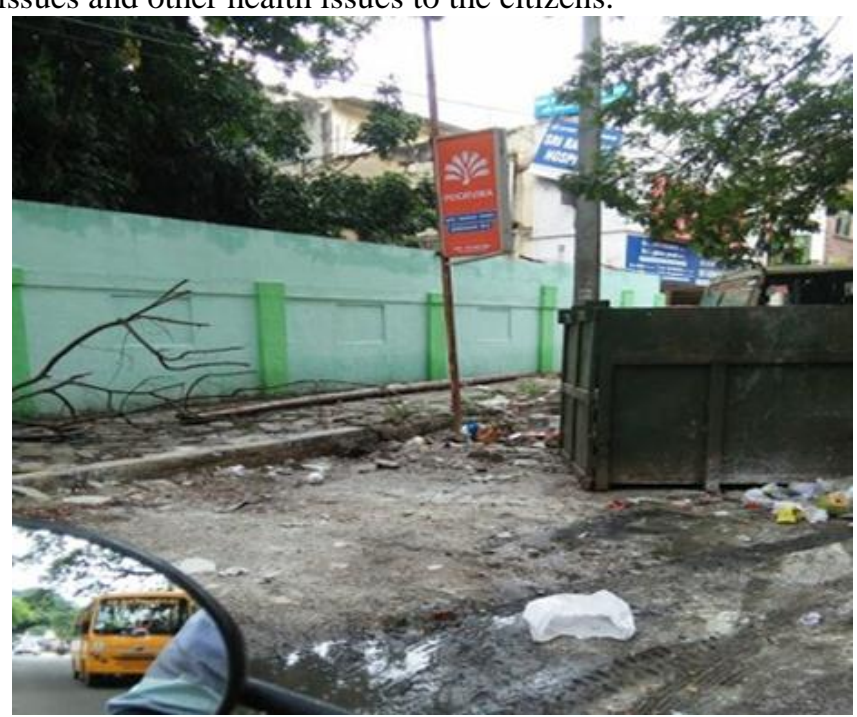

Figure 3: The damaged footpath and misplaced MSW bin

- $\quad$ On observing it has been identified that the stretch of D.B. road from the intersection of west Arokiasamy road and Ramachandra road with D.B. road, the pedestrian-vehicle conflicts is more and the chance of accidents are high. Since along this stretch of D.B. road, there are encroachments on footpath, it makes the pedestrians to use the MV lane for their movement. The same condition prevails in the stretch of D.B. road from the intersection of west Arokiasamy road to Kannusamy road. Here, the number of pedestrians crossing the road was found to be high. Also, the number of two wheelers parked for a shorter duration was also high in the later stretch of road. The reason for above was found to be the presence of 'Kovai pazhamudir nilayam' - a fruit and vegetable shop. Parking of vehicles was also found near the 'Annapoorna' bus stop which causes discomfort to public transport users.

In the intersection of D.B. road and T.V. Swamy road, the pedestrian crossings are more and it leads to conflicts with the motor vehicles. The observed movements of pedestrians and the possible incompatibility with the motorised vehicles is plotted and presented as an AutoCAD drawing as shown in figure 4 .

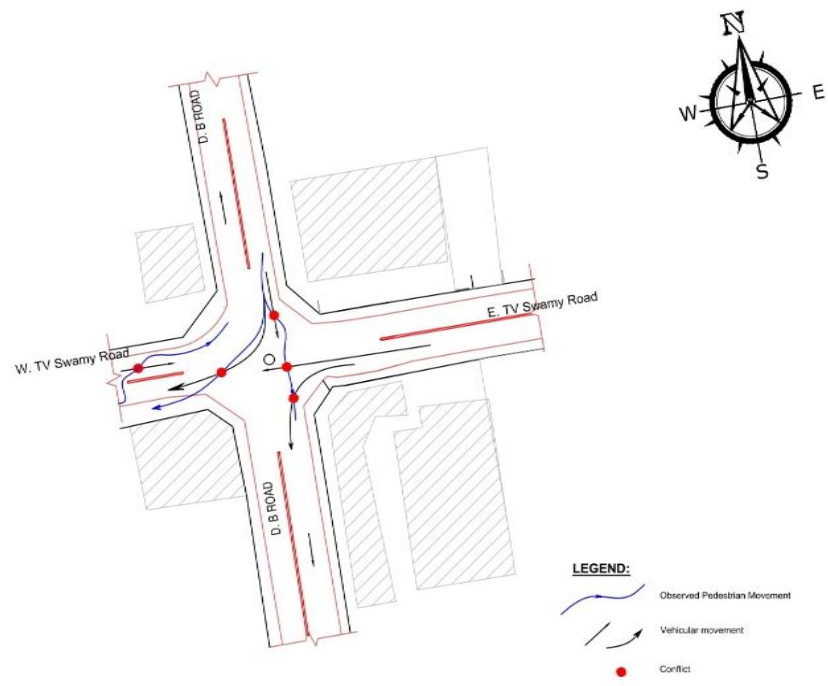

Figure 4: The possible conflicts at intersection of TV Swamy road and DB road.

The parking of vehicles on the footpath and near the traffic signal in the intersection causes difficulty for the pedestrians and for the drivers.

- In the stretch of D.B. road from west Periasamy road to the junction of Cowley Brown road, the pedestrian and flow was observed to be comparatively minimum.

- Near the 'Post office' bus stop (Refer figure 5), it was observed that there was parking permitted near bus stops. This will cause the passengers to get down the road.

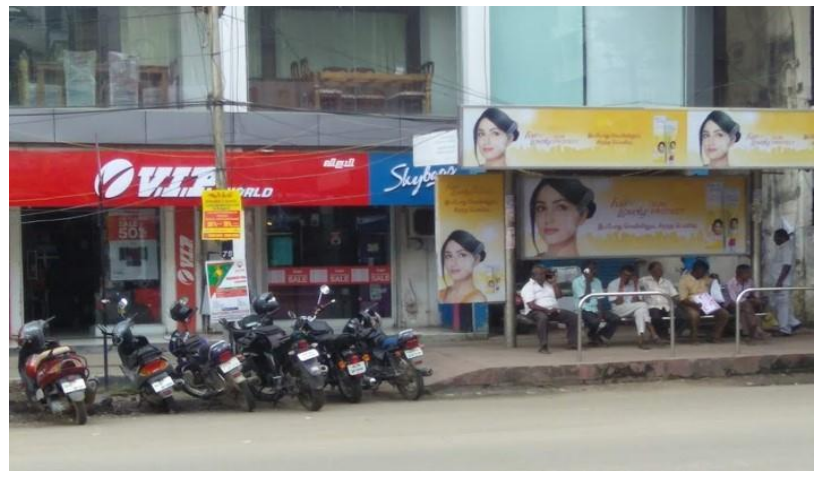

Figure 5: The parking of 2-wheelers near the 'Post office' bus-stop 
- Near the intersection of D.B. road and T.V. Swamy road, it was observed that the space allocated by having signage as 'Bi-cycle parking only' has been used for parking two wheelers (Refer figure 6). Also, there were no adequate facilities provided for parking of bicycles.

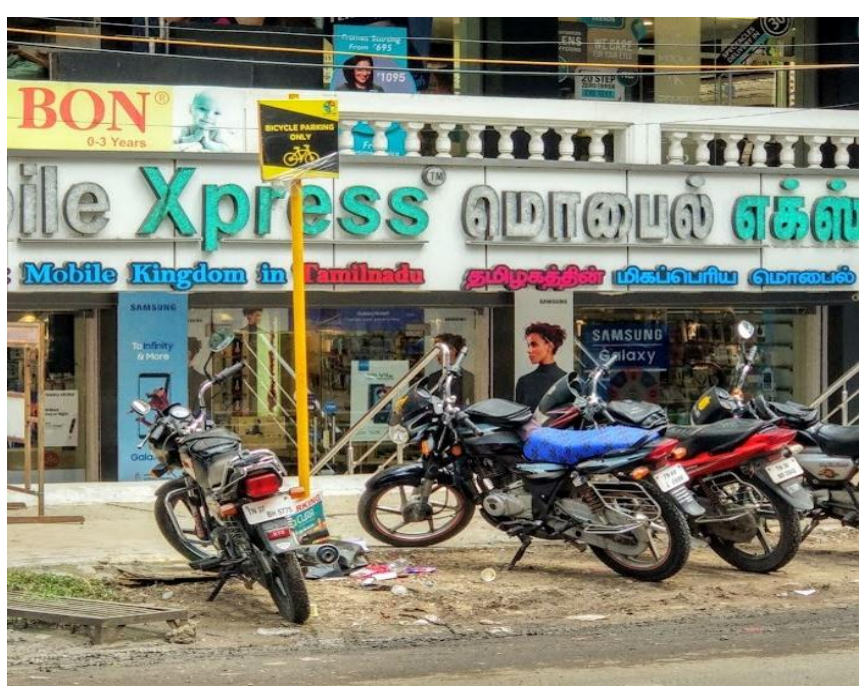

Figure 6: The parking of 2-wheelers at the Bi-Cycle parking $\underline{\text { area }}$

\section{Pedestrian survey}

Pedestrian survey informs the selection of pedestrian and liveability elements and design of traffic calming features. A pedestrian survey maps pedestrian movement to inform the expansion or improvement of pedestrian facilities. Observation of pedestrian movements and destinations can inform the placement and design of formal crossing. In case where pedestrians are not using the existing pathways, the survey can map possible reasons, such as insufficient width or conflicts with other uses. The data of the pedestrian count are given in table 1 .
Table 1: The numerical details of pedestrian count

\begin{tabular}{|l|c|}
\hline Pedestrian Manoeuvre & $\begin{array}{c}\text { Count } \\
\text { (pedestrians per } \\
\text { hour) }\end{array}$ \\
\hline Crossing & 472 \\
\hline Walking towards southern direction & 619 \\
\hline Walking towards northern direction & 268 \\
\hline Total & 1359 \\
\hline
\end{tabular}

The count was taken at D.B. road, near intersection of west Arokiasamy road and D.B. road, towards north and south directions. The number of pedestrians crossing is high in this area and hence a traffic calming measure can be suggested in this area.

\section{Cyclists survey}

Number of cyclists identified at D.B. road, near intersection of west Arokiasamy road and D.B. road towards north is 40 numbers. In order to effectively reduce the vehicular emissions and to reduce the traffic congestion on roads, the most efficient way is to reduce personalised motor transport and increase the quality of present pedestrian facilities. By this the use of NMT can be increased.

The count was taken at D.B. road, near intersection of west Arokiasamy road and D.B. road, towards north and south.

\section{Parking survey}

A parking survey should be conducted where a preliminary site visit suggests that demand for on street parking is high and causes conflicts with other activities. The survey can reveal imbalances in parking and suitable suggestions must be made. Figure 7 shows the existing location features of D.B. road drawn using AutoCAD software

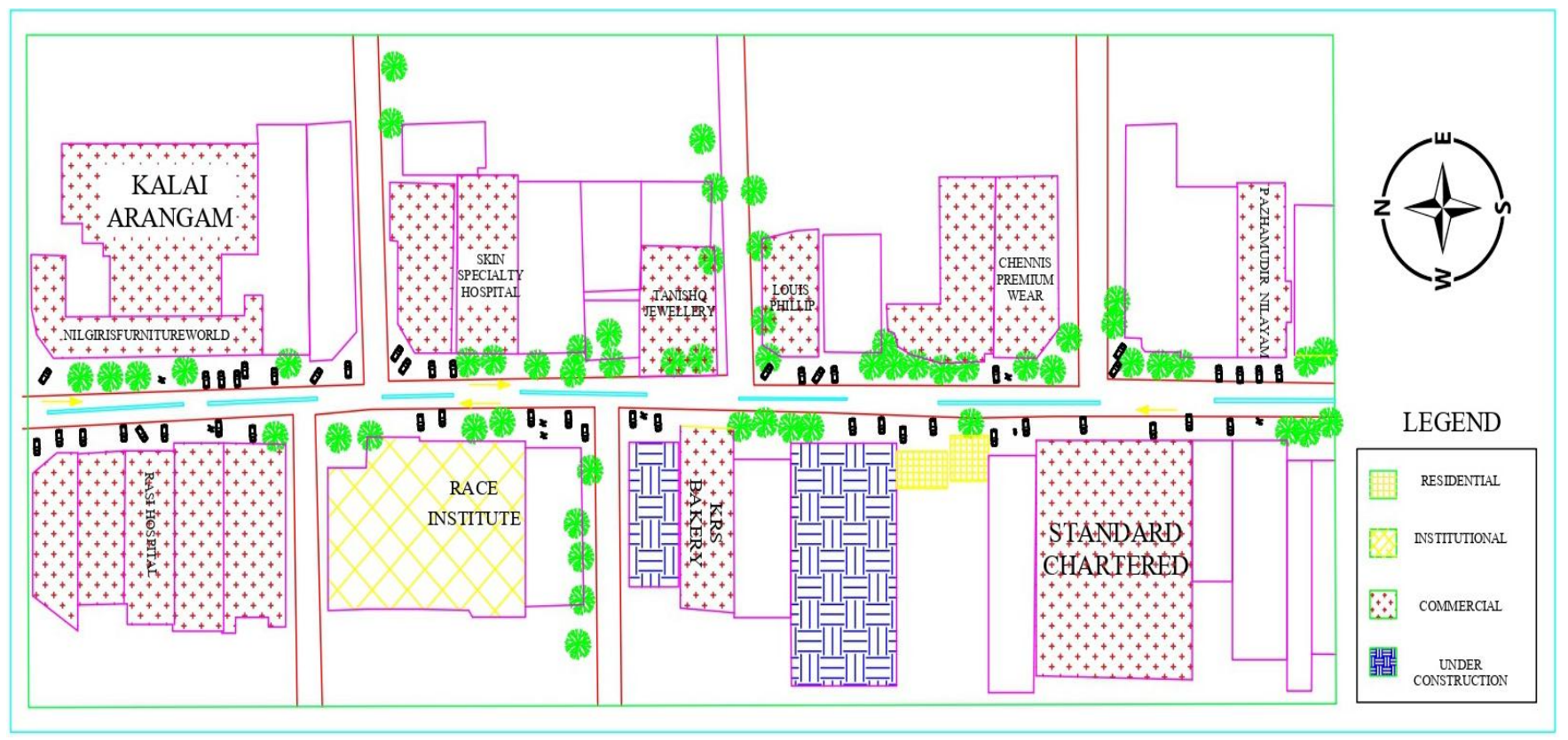

Figure 7: The existing site details of D.B. road. 
Parking survey is done by manually counting the number of parked vehicles at salient locations and then the values are incorporated in a tabular format as shown in table 2.

Table 2: The location details of parking count

\begin{tabular}{|c|c|c|c|c|}
\hline $\begin{array}{l}\text { Sl. } \\
\text { No. }\end{array}$ & $\begin{array}{l}\text { Location of } \\
\text { count }\end{array}$ & Type of vehicle & $\begin{array}{l}\text { Number of vehicles } \\
\text { (vehicles/hour) }\end{array}$ & $\begin{array}{l}\text { Ratio of number of } 4 \text {-wheelers } \\
\text { to number of } 2 \text {-wheelers }\end{array}$ \\
\hline \multirow[b]{2}{*}{1} & \multirow{2}{*}{$\begin{array}{l}\text { From 'Tanishq jewellery' to } \\
\text { 'Lens and Frames' }\end{array}$} & 2-wheeler & 108 & \multirow[b]{2}{*}{0} \\
\hline & & 4-wheeler & 0 & \\
\hline \multirow[b]{2}{*}{2} & \multirow{2}{*}{$\begin{array}{l}\text { From 'Lens and } \\
\text { Frames' to 'Chennis } \\
\text { premium wear' }\end{array}$} & 2-wheeler & 29 & \multirow[b]{2}{*}{$0.483 \approx 0.500$} \\
\hline & & 4-wheeler & 14 & \\
\hline \multirow[b]{2}{*}{3} & \multirow{2}{*}{$\begin{array}{l}\text { From 'Chennis } \\
\text { premium wear' to } \\
\text { 'Pazhamudir } \\
\text { nilayam' }\end{array}$} & 2-wheeler & 74 & \multirow[b]{2}{*}{0.041} \\
\hline & & 4-wheeler & 3 & \\
\hline \multirow[b]{2}{*}{4} & \multirow{2}{*}{$\begin{array}{l}\text { From Int. of D.B. Rd. } \\
\text { and W. Ramalingam } \\
\text { Rd. to Int. of W. } \\
\text { Arunachalam Rd. } \\
\text { and D.B. Rd. }\end{array}$} & 2-wheeler & 5 & \multirow[b]{2}{*}{5.2} \\
\hline & & 4-wheeler & 26 & \\
\hline
\end{tabular}

The parking survey should determine the number, type, orientation and location of parked vehicles over the entire area to be designed. Rickshaw and taxi points should also be shown because they compete with other vehicles and will idle in the carriageway if they cannot find suitable short term on-street parking.

The above data has been represented in a graphical format in figure 8 . This graph shows the number of 2-wheelers parked. In figure 8 , Sl. No: 1,2,3 and 4 represents the corresponding serial numbers (Refer table 2).

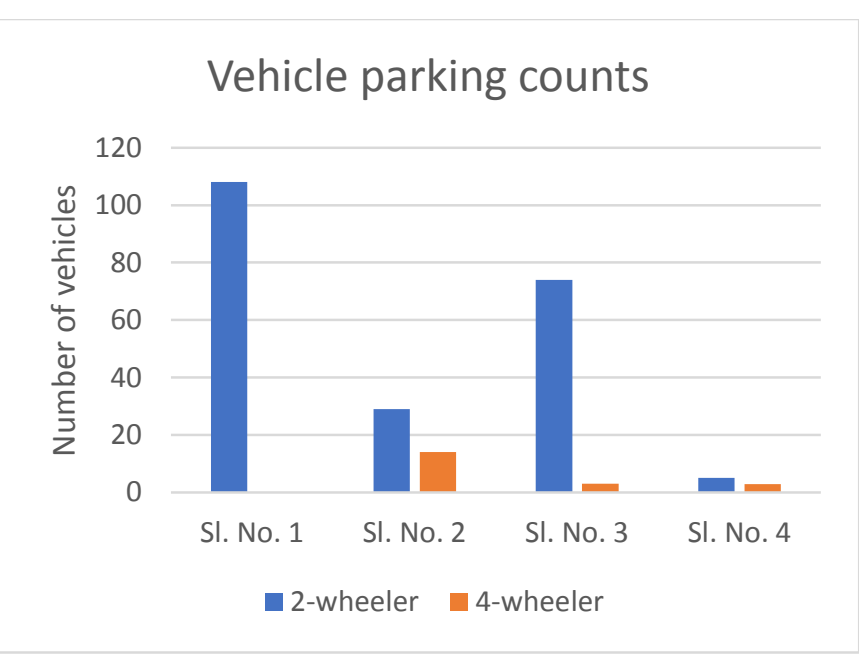

Figure 8: The vehicle parking count taken at the specified stretch of D.B. road

\section{Right of way overlay}

Municipal authorities can provide right of way width but generally do not have maps showing precise, geocoded locations of the public right of way. Hence, a right of way must be defined using information from the topographic survey. Figure 9 depicts the topographic feature around the existing intersection.

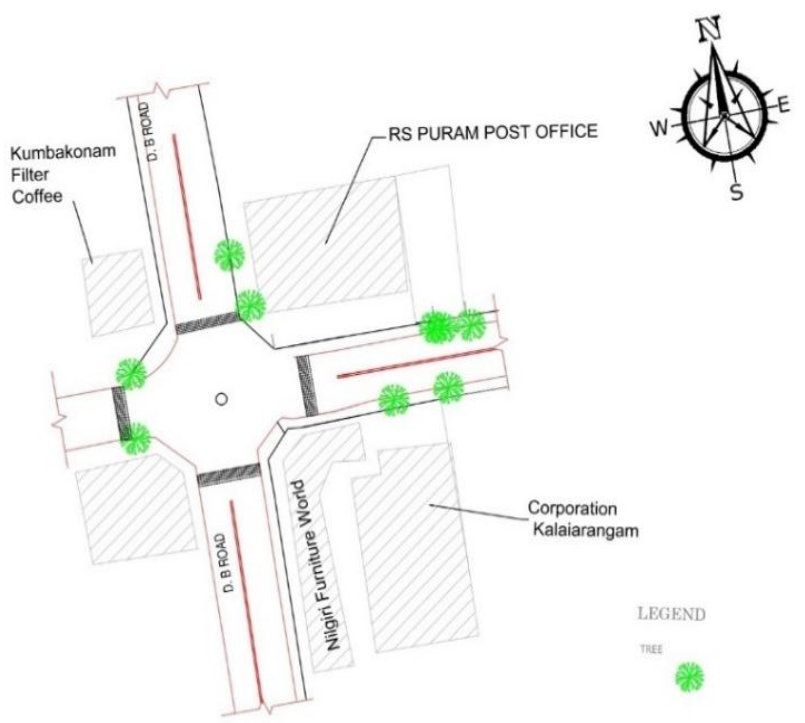

Figure 9: The D.B. Rd and T.V Swamy Rd intersection detail as AutoCAD drawing 
Area of land acquired for road along its alignment. Width depends on the importance of the road and possible future development. The right of way is typically determined based on the building and compound wall locations. The right of way is adjusted such that the demolitions are minimum.

- RoW for D.B. road is $21 \mathrm{~m}$ (Arterial road).

- Average existing land width (Carriageway + footpath, etc.) is $17 \mathrm{~m}$.

- Land width required to meet RoW is $4 \mathrm{~m} \mathrm{(2} \mathrm{m} \mathrm{on} \mathrm{either}$ sides).

- With existing land features and the commercial centres on either side of D.B. road, it is impossible to extend $2 \mathrm{~m}$ on either side.

- So, the right of way can be fixed as $18 \mathrm{~m}$ such that this can be accommodated on any one side or $0.5 \mathrm{~m}$ on either side of D.B. road.

\section{$\underline{\text { Traffic survey }}$}

The traffic survey quantifies vehicle movements, including non-motorised vehicle traffic, supplementing the pedestrian survey. Data from the traffic survey are necessary for intersection design and signal timing optimization. Vehicles are counted during the peak period when traffic volumes and space requirements are highest. Figure 10 shows the position of each observer at each arm.
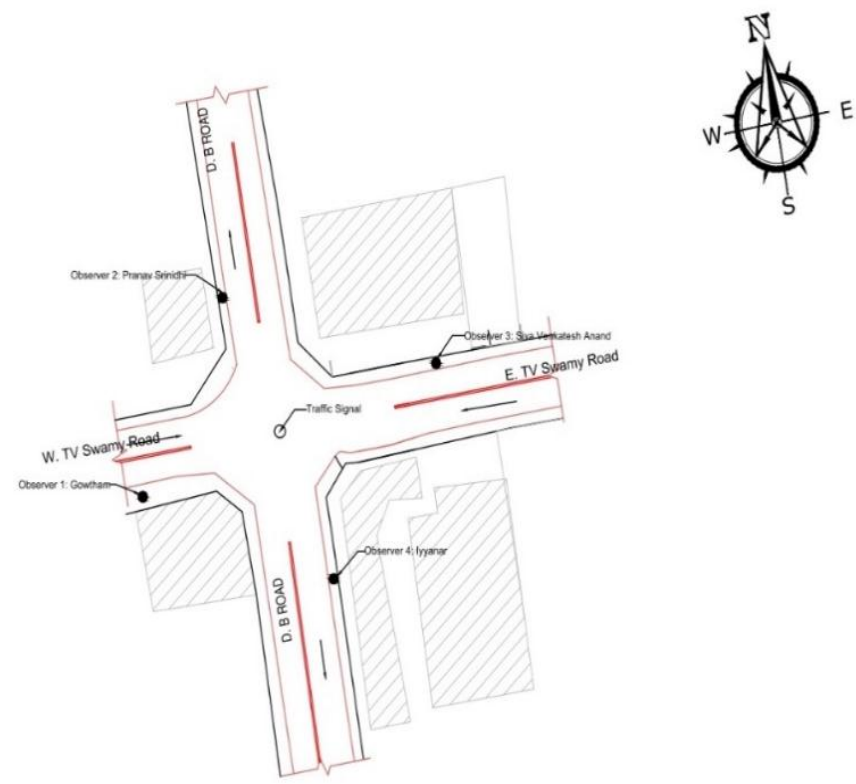

Figure 10: The details of position of observers
Table 3: Shows the details of the traffic survey carried out.

Table 3: Traffic survey details

\begin{tabular}{|l|l|}
\hline Method of survey & Manual method \\
\hline Place of survey & $\begin{array}{l}\text { Int. of D.B. road and T.V. Swamy } \\
\text { road }\end{array}$ \\
\hline Date / Day & 03-October-2018 / Wednesday \\
\hline Time & $09: 20$ A.M to 10:20 A.M \\
\hline Type of intersection & Signalised \\
\hline Number of arms & 4 arms (both two-way traffic) \\
\hline Left turn pocket & Not Available \\
\hline Pedestrian crossing & Not Available \\
\hline Pedestrian signals & Not Available \\
\hline
\end{tabular}

Counts can be conducted on site or from a video recording. The count should be classified by vehicle type. For a manual survey of a typical signalised four-way intersection, one surveyor can stand at each arm, counting the incoming traffic. This is easier than counting outgoing traffic because each incoming movement occurs during a different signal phase. However, for design of the signal phasing, movements are grouped by outgoing direction.

The traffic volume that is travelling out of each arm, converted in to equivalent passenger car units is as shown in the following figures respectively for each arm. Figure 11, 12, 13 and 14 furnishes the details of number of each category of incoming vehicles to West T.V. Swamy road, North D.B. road, East T.V. Swamy road, South D.B. road, respectively.

PCU values are calculated for vehicles leaving from each arm (Refer table 4) with reference to the adopted PCU values. These adopted values for design are given in table 3 of IRC:86-1983. 


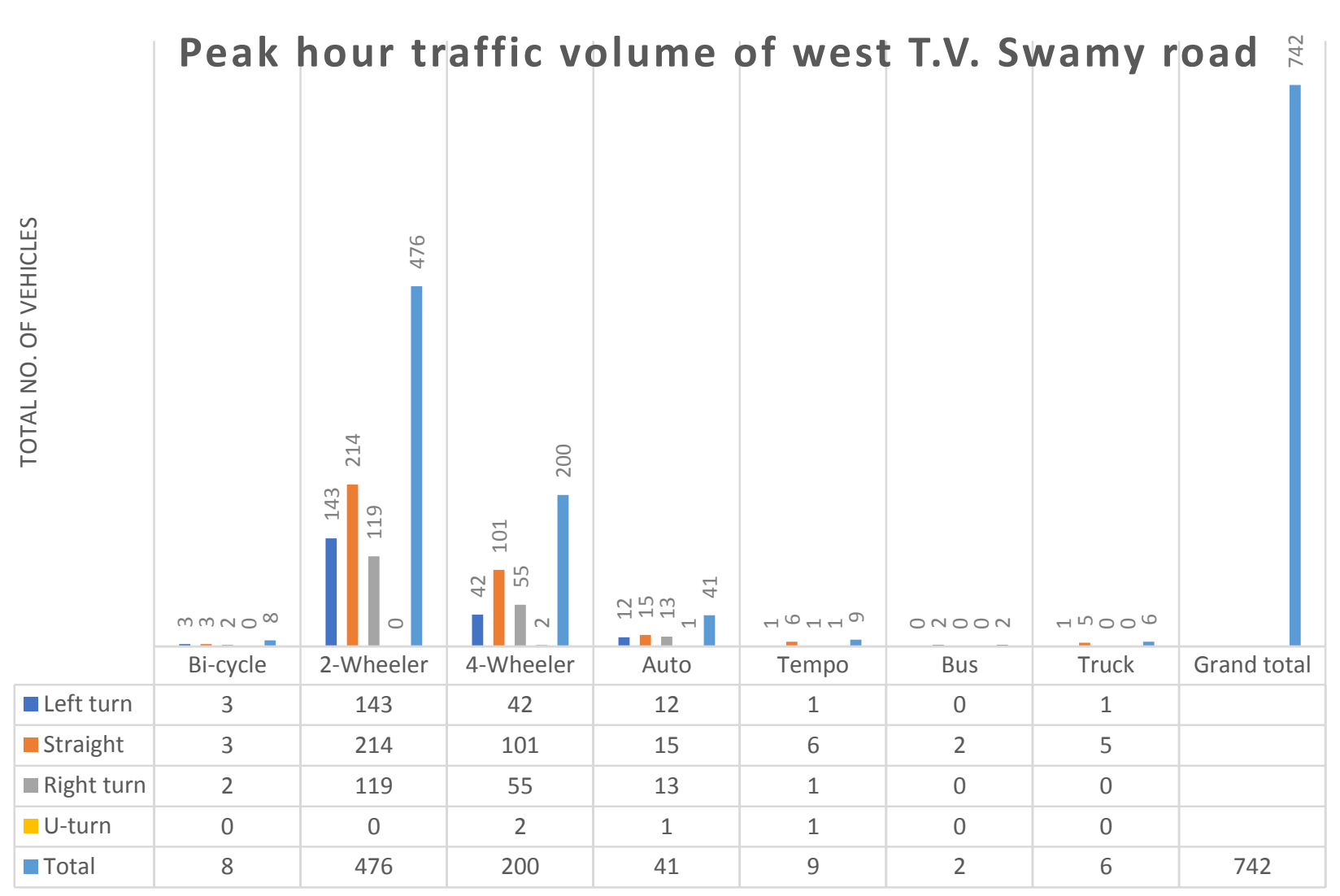

Figure 11: The graphical representation of peak hour traffic volume of West T.V. Swamy road

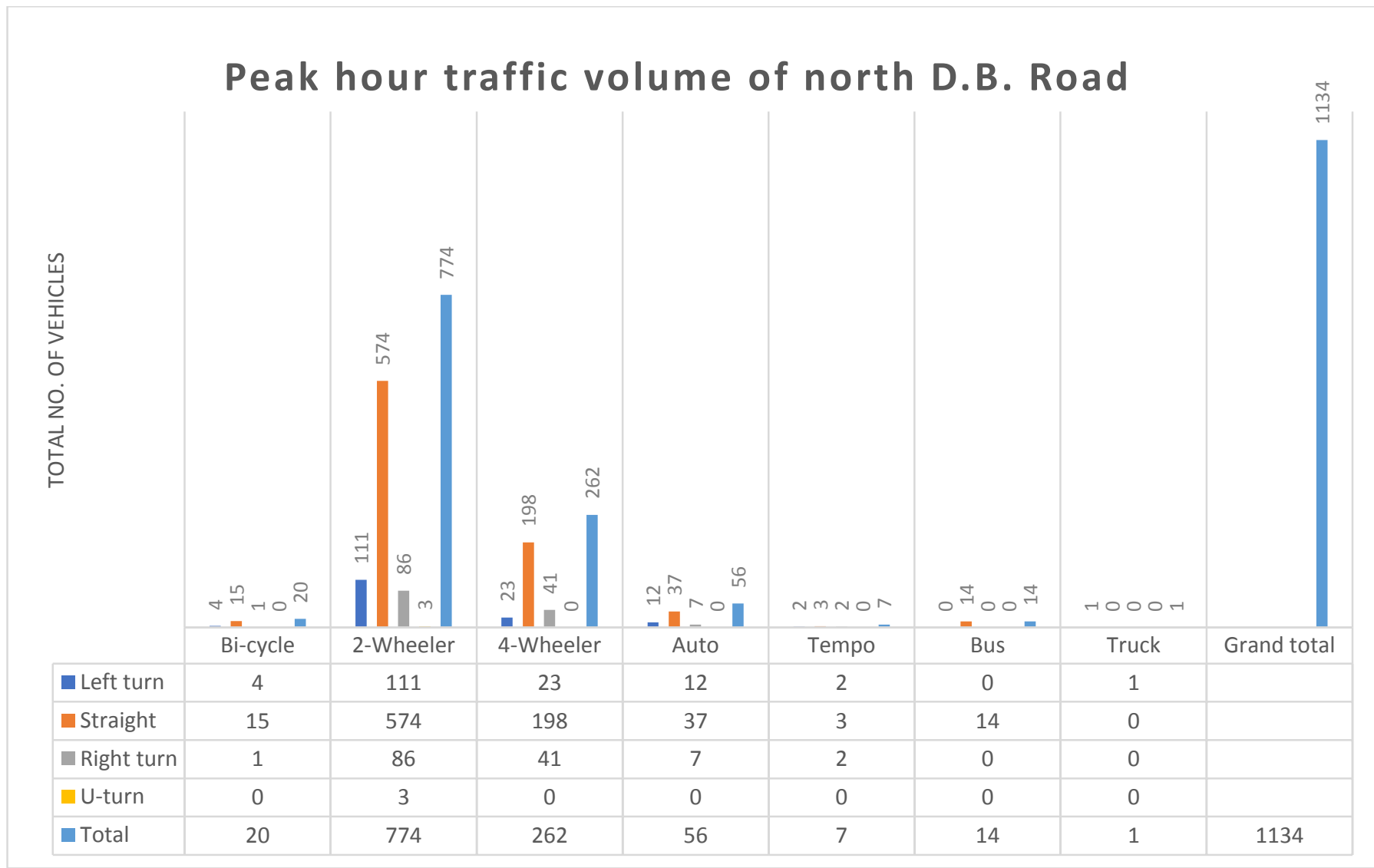

Figure 12: The graphical representation of peak hour traffic volume of North D.B. road 


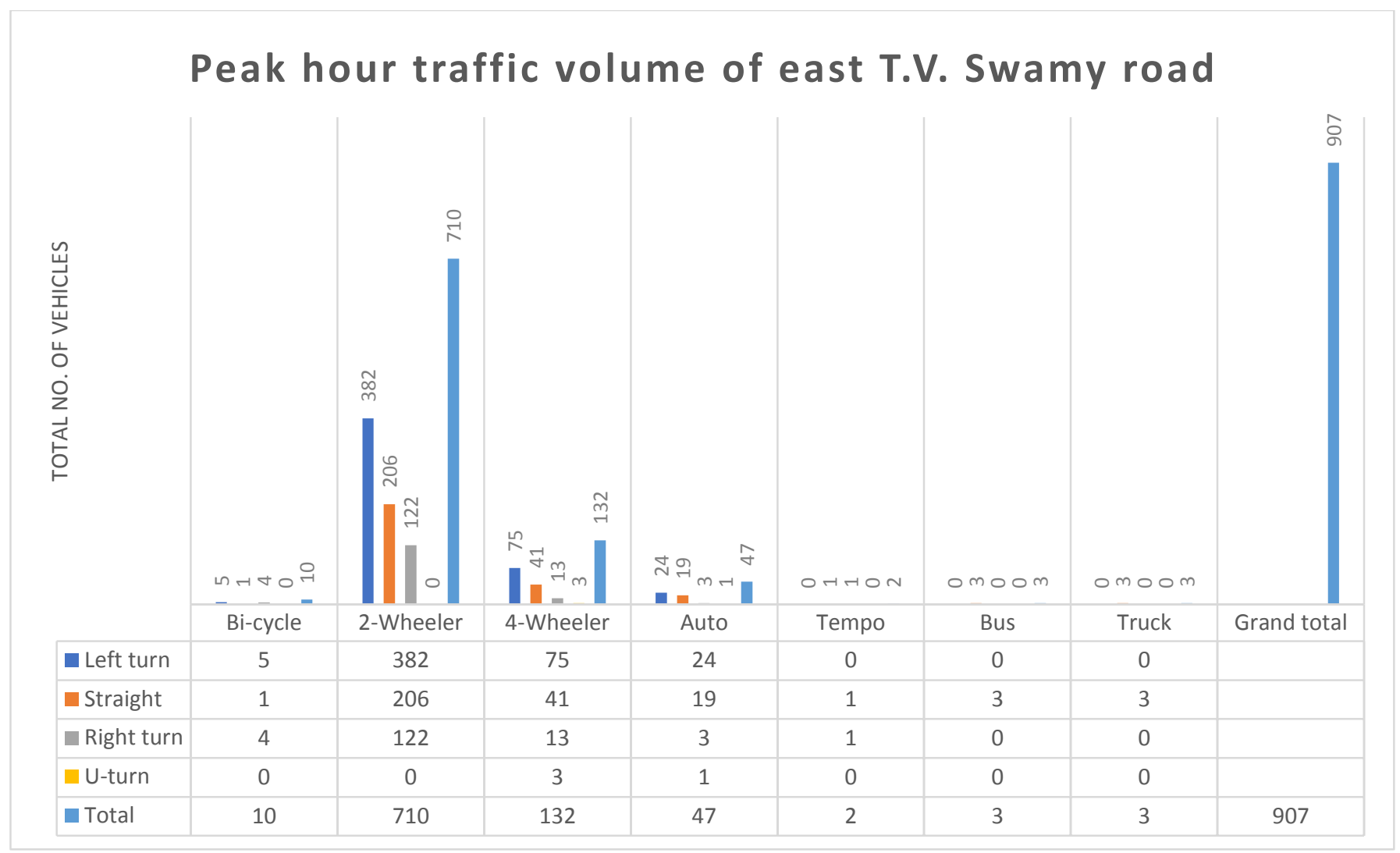

Figure 13: The graphical representation of peak hour traffic volume of East T.V. Swamy road

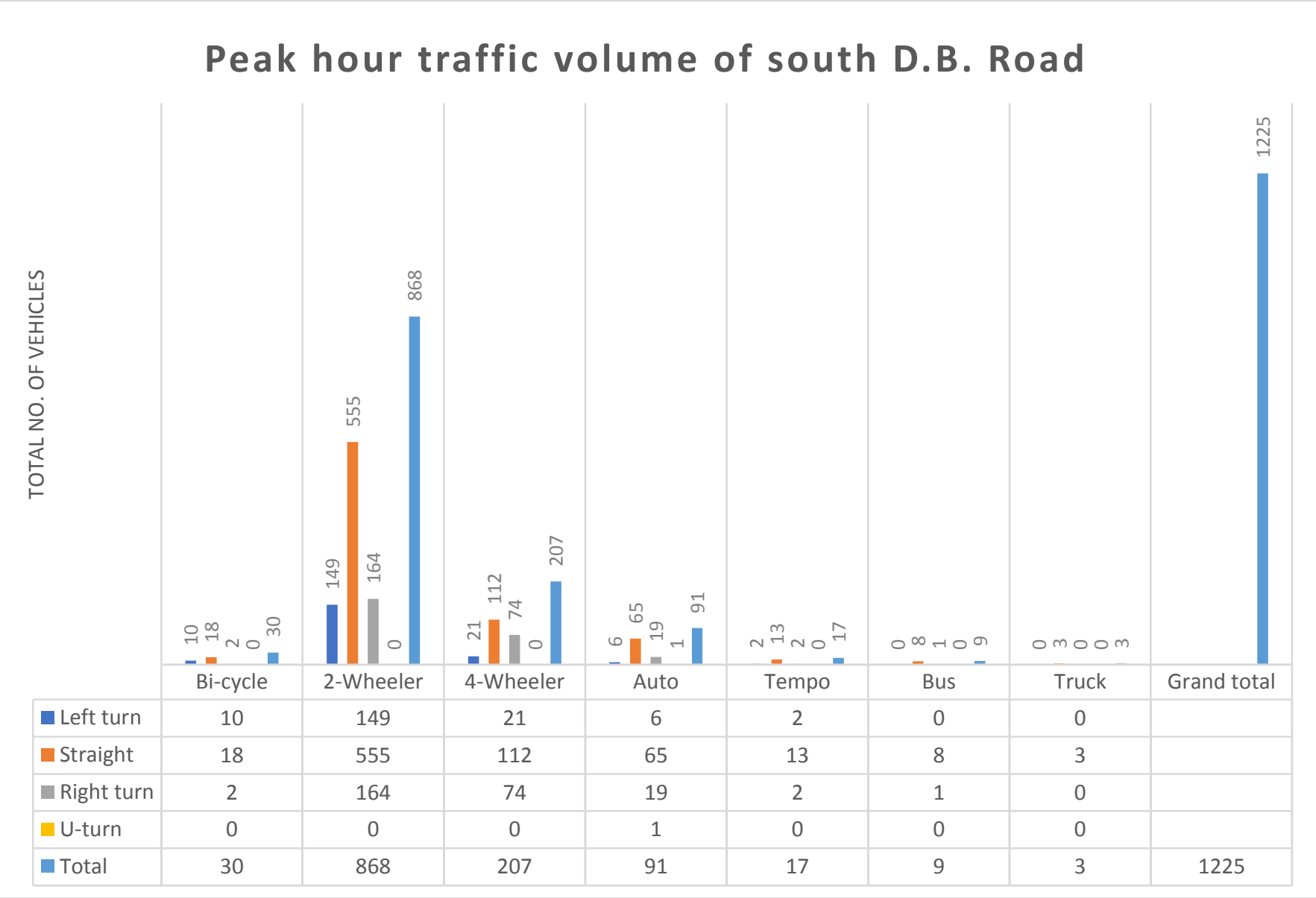

Figure 14: The graphical representation of peak hour traffic volume of South D.B. road 
International Journal of Applied Engineering Research ISSN 0973-4562 Volume 16, Number 5 (2021) pp. $423-440$

(C) Research India Publications. https://dx.doi.org/10.37622/IJAER/16.5.2021.423-440

Table 4: PCU values calculated for vehicles leaving from each arm

\begin{tabular}{|c|c|c|c|c|c|c|c|c|c|c|c|c|c|}
\hline \multirow{3}{*}{$\begin{array}{l}\text { TYPE OF } \\
\text { VEHICLE }\end{array}$} & \multirow{3}{*}{$\begin{array}{c}\text { PCU } \\
\text { (As per IRC: } \\
86-1983 \\
\text { Table 3) }\end{array}$} & \multicolumn{12}{|c|}{ TOTAL NUMBER OF VEHICLES LEAVING THE ARM (pcu/hr) } \\
\hline & & \multicolumn{3}{|c|}{ West TV Swamy Road } & \multicolumn{3}{|c|}{$\begin{array}{c}\text { East TV Swamy } \\
\text { Road }\end{array}$} & \multicolumn{3}{|c|}{ DB Road - North } & \multicolumn{3}{|c|}{ DB Road - South } \\
\hline & & $\begin{array}{c}\text { Straig } \\
\text { ht }\end{array}$ & Left & Right & $\begin{array}{c}\text { Straig } \\
\text { ht }\end{array}$ & Left & $\underset{t}{\text { Righ }}$ & $\begin{array}{c}\text { Straig } \\
\text { ht }\end{array}$ & Left & Right & $\begin{array}{c}\text { Straig } \\
\text { ht }\end{array}$ & Left & Right \\
\hline Cycle & 0.50 & 1.50 & 1.50 & 1.00 & 0.50 & 2.50 & 2.00 & 7.50 & 2.00 & 0.50 & 9.00 & 5.00 & 1.00 \\
\hline Two Wheeler & 0.50 & 107.00 & 71.50 & 59.50 & 103.00 & $\begin{array}{c}191.0 \\
0\end{array}$ & 61.00 & 287.00 & $\begin{array}{c}55.5 \\
0\end{array}$ & 43.00 & 277.50 & 74.50 & 82.00 \\
\hline $\begin{array}{l}\text { Four Wheeler } \\
\text { (Car) }\end{array}$ & 1.00 & 101.00 & 42.00 & 55.00 & 41.00 & 75.00 & 13.00 & 198.00 & $\begin{array}{c}23.0 \\
0\end{array}$ & 41.00 & 112.00 & 21.00 & 74.00 \\
\hline Auto & 1.00 & 15.00 & 12.00 & 13.00 & 19.00 & 24.00 & 3.00 & 37.00 & $\begin{array}{c}12.0 \\
0\end{array}$ & 7.00 & 65.00 & 6.00 & 19.00 \\
\hline Tempo & 1.00 & 6.00 & 1.00 & 1.00 & 1.00 & -- & 1.00 & 3.00 & 2.00 & 2.00 & 13.00 & 2.00 & 2.00 \\
\hline Bus & 3.00 & 6.00 & -- & -- & 9.00 & -- & -- & 42.00 & -- & -- & 24.00 & -- & 3.00 \\
\hline Trucks & 3.00 & 15.00 & 3.00 & -- & 9.00 & -- & -- & -- & 3.00 & -- & 9.00 & -- & -- \\
\hline Total (pcu/hr) & & $\begin{array}{c}251.5 \\
0\end{array}$ & $\begin{array}{c}131 . \\
00\end{array}$ & $\begin{array}{c}129.5 \\
0\end{array}$ & $\begin{array}{c}182.5 \\
0\end{array}$ & $\begin{array}{c}292 . \\
50\end{array}$ & $\begin{array}{c}80.0 \\
0\end{array}$ & $\begin{array}{c}574.5 \\
0\end{array}$ & $\begin{array}{c}97.5 \\
0\end{array}$ & 93.50 & $\begin{array}{c}509.5 \\
0\end{array}$ & $\begin{array}{c}108.5 \\
0\end{array}$ & $\begin{array}{c}181.0 \\
0\end{array}$ \\
\hline
\end{tabular}

Then the total PCU per hour value (Refer table 5) for each road is calculated by summing the total PCU/hour values in Straight, left and right direction individually for traffic moving out of each road. The total number of vehicles per hour in table 5 is represented as the grand total value in figure 11, 12, 13 and 14 for each road individually.

Table 5: Total PCU per hour values at each arm

\begin{tabular}{|l|c|c|}
\hline \multicolumn{1}{|c|}{ Name of the arm } & $\begin{array}{c}\text { Total number of } \\
\text { vehicles per hour }\end{array}$ & $\begin{array}{c}\text { Total PCU } \\
\text { per hour }\end{array}$ \\
\hline West T.V. Swamy road & 742 & 512 \\
\hline East T.V. Swamy road & 904 & 555 \\
\hline D.B. road - North & 1134 & 765.5 \\
\hline D.B. road - South & 1225 & 799 \\
\hline
\end{tabular}

\section{$\underline{\text { Traffic signal redesign }}$}

In this study, the signal design had been carried out as per, "IRC: 93-1985: Guidelines on design and installation of road traffic signals" [2]. In Indian practice of signal phasing, an amber period of 2 seconds as a transition interval between termination of related green movement and exhibition of a red indication or between termination of red indication and commencement of related green movement is used.

As per 'Code of practice for urban roads (Part 2)' prepared by the TRIPP ${ }^{[9]}$ for the Institute of Urban Transport, Ministry of Urban Development, Government of India; the minimum vehicular volume required for signalised intersection is given in table 6.
Table 6: Minimum vehicular volume required for signalised intersection as suggested by TRIPP

\begin{tabular}{|c|c|c|c|}
\hline \multicolumn{2}{|l|}{$\begin{array}{l}\text { Number of lanes for } \\
\text { moving traffic on each } \\
\text { approach }\end{array}$} & $\begin{array}{l}\text { Motor per } \\
\text { vehicle per } \\
\text { hour on } \\
\text { major street } \\
\text { (both the } \\
\text { direction) }\end{array}$ & $\begin{array}{l}\text { Motor vehicle } \\
\text { per hour on } \\
\text { minor street } \\
\text { (one direction) }\end{array}$ \\
\hline $\begin{array}{l}\text { Major } \\
\text { street }\end{array}$ & $\begin{array}{l}\text { Minor } \\
\text { street }\end{array}$ & 650 & 200 \\
\hline 1 & 1 & 800 & 200 \\
\hline 2 or more & 1 & 800 & 250 \\
\hline 1 & 2 or more & 650 & 250 \\
\hline
\end{tabular}

Both D.B. road and T.V. Swamy road are major roads and in both the roads there are 2 lanes. From the traffic survey, the peak hour flow for T.V. Swamy road is $1067 \mathrm{PCU} /$ hour in both the directions and that for D.B. road is 1564 PCU/hour. Referring to table 5, the actual peak hour flow is more than the minimum permit suggested by the 'Code of practice for urban roads (Part 2) ${ }^{\text {, }}{ }^{\text {[9] }}$. Hence provision of traffic signal is inevitable in this intersection.

\section{$\underline{\text { Traffic signal design-calculation }}$}

The following are the assumptions as per "IRC: 93-1985Guidelines on design and installation of road traffic signals" [2];

Pedestrian speed $-1.2 \mathrm{~m} / \mathrm{s}$, Reaction time - 2 seconds, Deceleration rate $-4 \mathrm{~m} / \mathrm{s}^{2}$, Average length of the vehicle $-5 \mathrm{~m}$ and velocity of the vehicle is assumed as same as the design speed of street. For arterial streets, as per 'Coimbatore street design and management policy' ${ }^{[2]}$ published by ITDP, 2017, the maximum design speed can be assumed as $50 \mathrm{kmph}$. The following formulae described in 'Highway engineering' ${ }^{[10]}$ and 'Traffic engineering and Transport planning' ${ }^{[11]}$ are used for 
signal timing re-design;

$$
\begin{aligned}
& T_{a}=T_{r}+\frac{V}{2 D}+\frac{(W+L)}{V} \\
& T_{p}=7+\frac{W}{1.2} \\
& \mathrm{~S}=525 \mathrm{~W} \\
& Y=\frac{q}{s} \\
& L=L_{m}+L_{r}(\text { Here, } L=\text { total lost time for each phase }) \\
& L_{o}=\frac{1.5 L+5}{1-Y}
\end{aligned}
$$$$
L_{e}=L_{o}-L
$$

$$
\begin{aligned}
& G=\frac{Y_{i}}{Y} \times L_{e} \\
& R=L_{a}-G-L
\end{aligned}
$$

The above equations $\{(\mathrm{i})$ to (ix) $\}$ are explained in the abbreviation section of this article. After calculating the signal timings individually foreach of the four phases (Refer figure 2), the existing and proposed signal timings are represented graphically (Refer figure 15 and 16). Figure 15 and 16 shows the comparison for both red and green signal timings in different phases respectively.

\section{Comparison of calculated red signal timings}

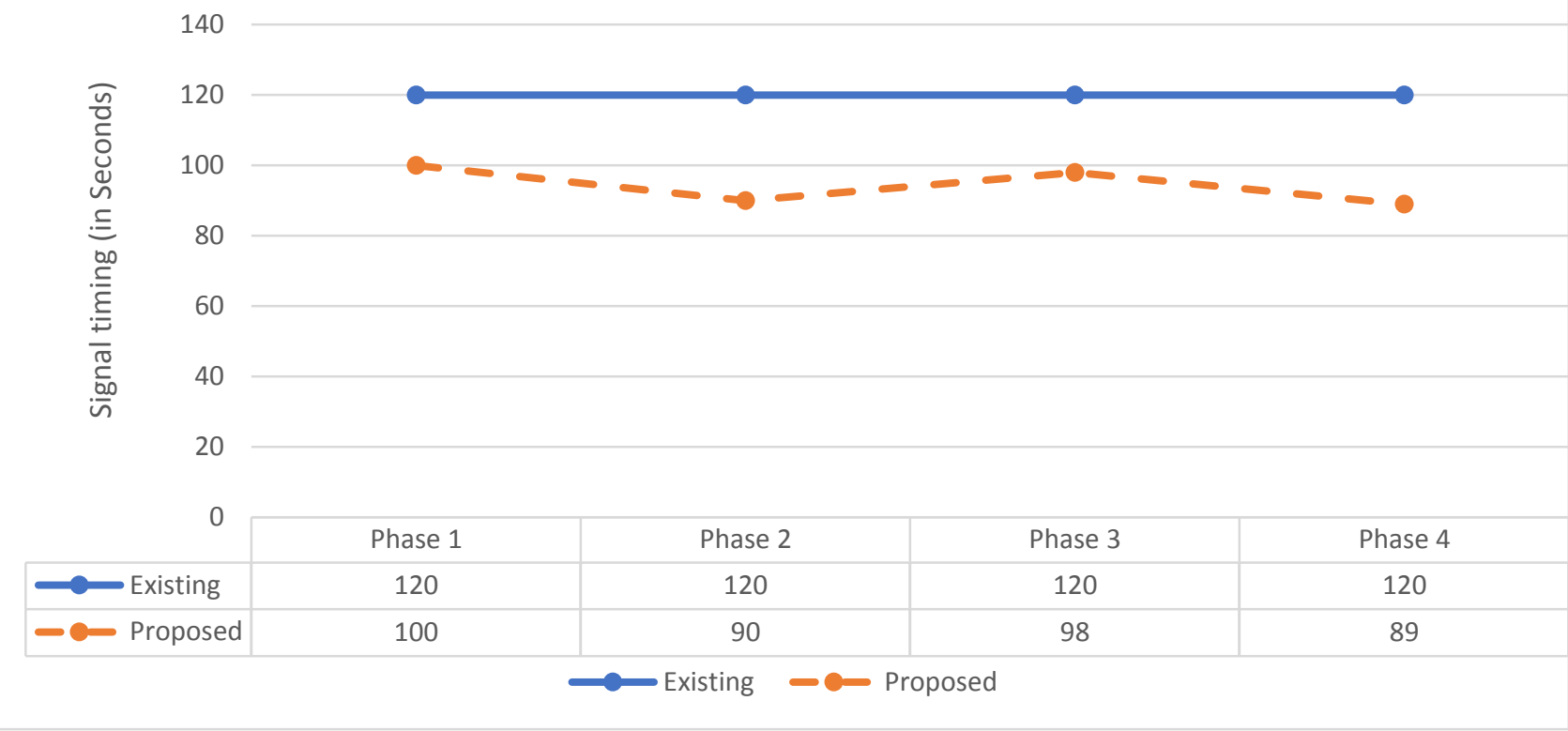

Figure 15: Comparison of calculated red signal timings in different phases

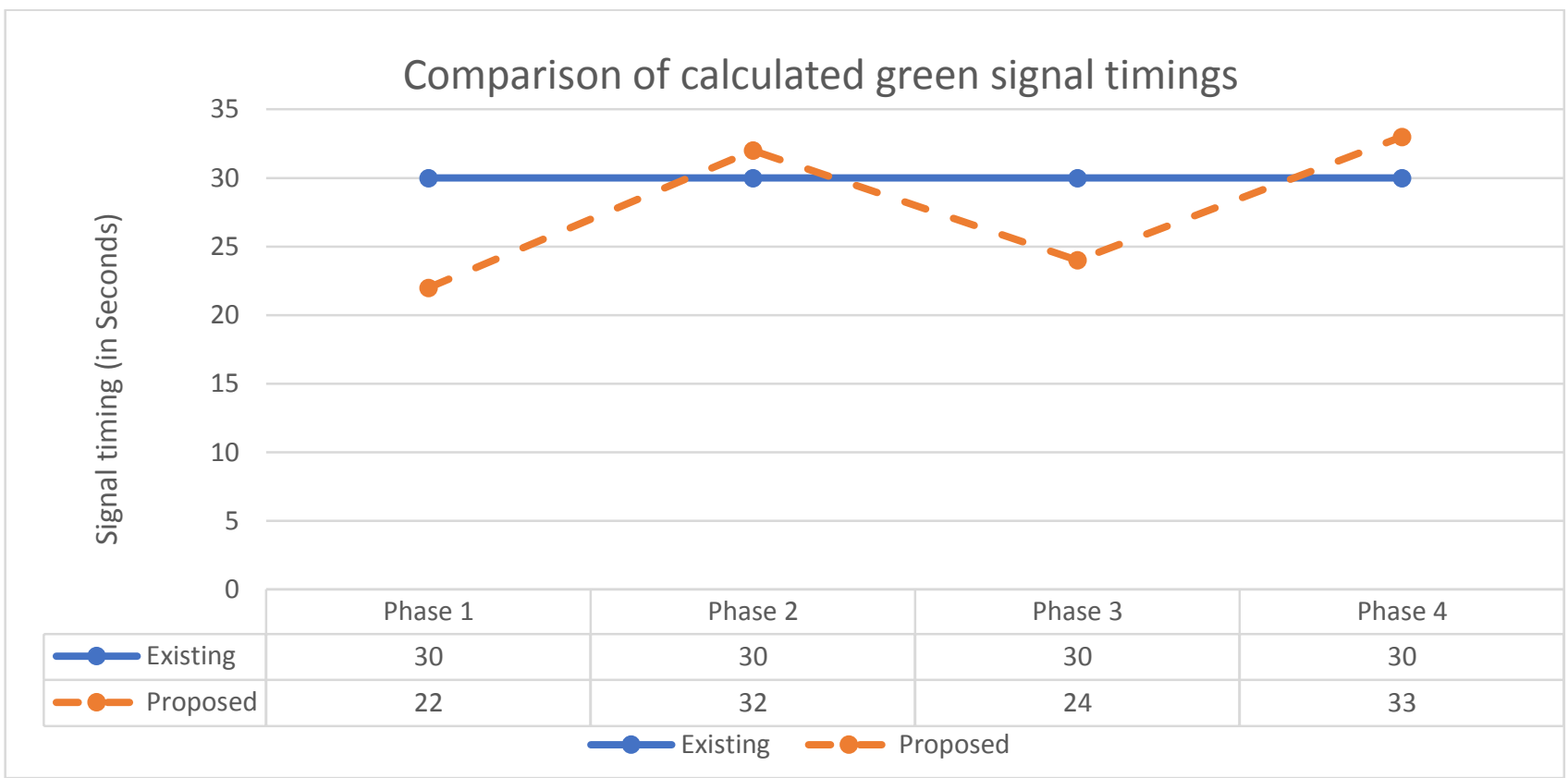

$\underline{\text { Figure 16: Comparison of calculated green signal timings in different phases }}$ 


\section{Proposal of street cross-section}

Once all the above-mentioned surveys are done, by comparing the results with the standards, final cross-section of the proposed street was achieved. All the widths were arrived only after referring to respective standards. The main aim of this street design is to provide ample amenities for the nonmotorized traffic flow. The important thing to consider is that where there is a bus stop (Refer figure 18), the parking is prohibited before the bus stop in both the directions and that width has been utilized for provision of bus shelter.

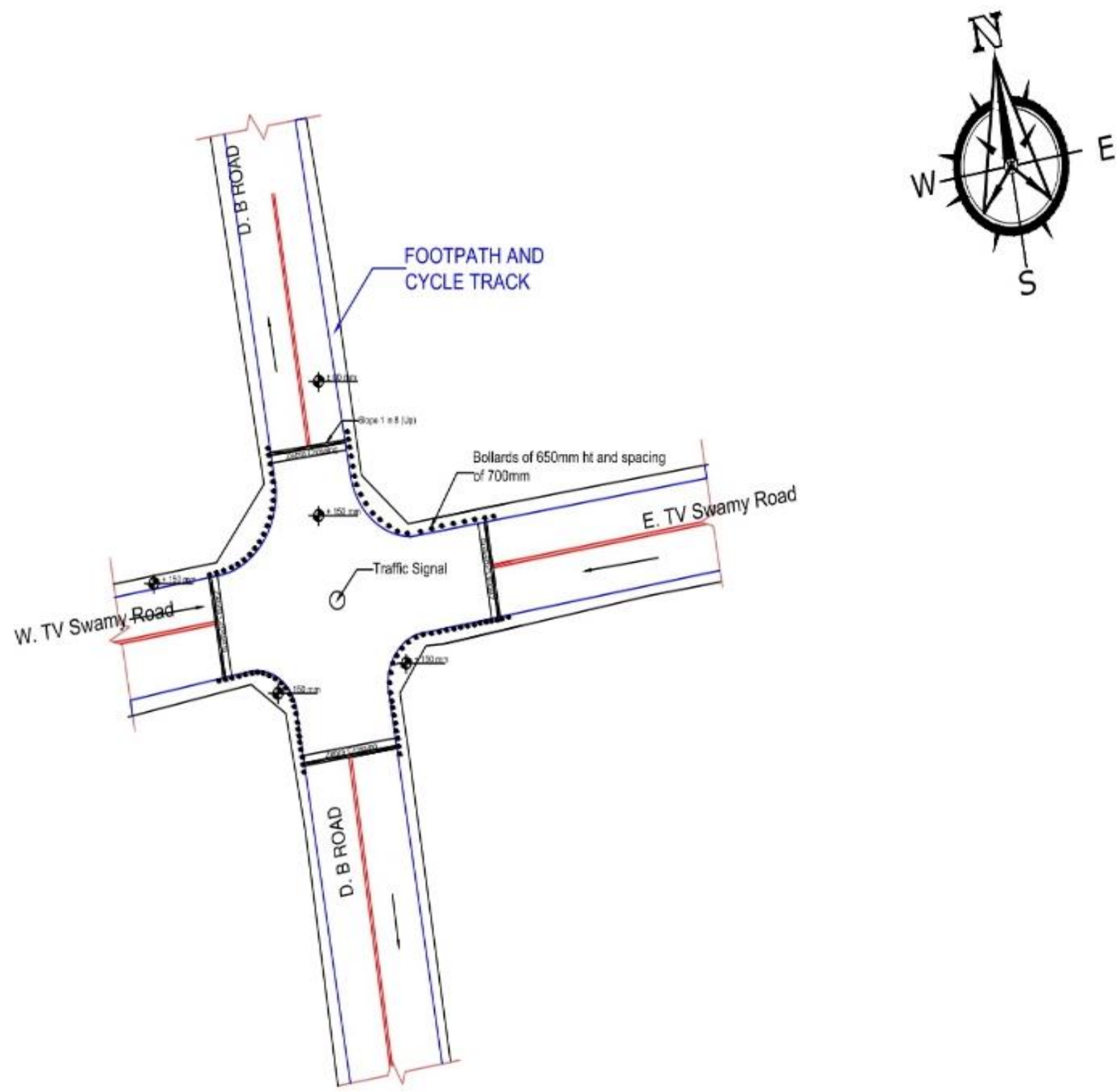

\section{Major intersection design}

The intersection of two roads is to be designed such that there is no problem for the cyclists and pedestrian crossings. Also, the vehicles that approach the intersection should also be passed without much delay. Reduction of accidents is an important criterion in the intersection design. In the view of all the above, the intersection of D.B. road and T.V. Swamy road has been designed and it is shown in figure 17.

The detail of the designed intersection is furnished in table 7.

Figure 17: Shows the details of the proposed intersection using AutoCAD drawing 
International Journal of Applied Engineering Research ISSN 0973-4562 Volume 16, Number 5 (2021) pp. $423-440$

(C) Research India Publications. https://dx.doi.org/10.37622/IJAER/16.5.2021.423-440

Table 7: Shows the details of the proposed intersection

\begin{tabular}{|l|l|l|}
\hline Elements & Existing & Proposed \\
\hline Type of intersection & Signalised & Signalised \\
\hline Type of crossing & At grade & Table top crossing at $150 \mathrm{~mm}$ height using ramp at 1:8 \\
\hline Zebra crossing & NA & $\begin{array}{l}\text { Available with a width of } 2.5 \mathrm{~m} \text { consisting of evenly spaced white } \\
\text { stripes of } 500 \mathrm{~mm} \text { width }\end{array}$ \\
\hline Number of signal phase & 4 & 4 \\
\hline $\begin{array}{l}\text { Signal phase available for } \\
\text { cyclists and pedestrians }\end{array}$ & NA & May be implemented after proposing \\
\hline Bollards & NA & Available with a height of $650 \mathrm{~mm}$ and $750 \mathrm{~mm}$ spacing \\
\hline
\end{tabular}

\section{Public transport design}

Public transport design includes the design of BRT lanes that are provided in major streets. So far, there are no BRT lanes are being provided in any major streets of Coimbatore.

All the mentioned roads have their right of way greater than or equal to $22 \mathrm{~m}$ and hence implementation of BRT systems was easier.

Since D.B. road has a right of way lesser than $22 \mathrm{~m}$ and the proposed carriage-way is also narrower, it would be difficult in implementing the BRT system. Hence there is no separate public transport design and the buses travel along with the mixed traffic.

\section{Minor street intersection}

Where a minor street intersects the major street, the following points are notable;

- The footpath and cycle tracks shall be continuous along the path.

- Separate ramps at gradient of 1:8 shall be provided to connect the streets.

- Bollards shall be provided at suitable spacing to prevent the entry of motorized vehicles.

\section{RESULTS:}

\section{Footpath}

- Essentially a footpath consists of three component - dead width, pedestrian zone and furniture zone (with tree plantations)

- As per IRC: 103-2012, minimum dead width is $0.5 \mathrm{~m}$

- Assuming a plantation and furniture zone of $0.5 \mathrm{~m}$

- The total width of the footpath $=0.5+2.5+0.5=3.5 \mathrm{~m}$

- Also, the minimum clear height of the footpath required for good vision $=2.2 \mathrm{~m}$

\section{Cycle track}

- As per table 7 of 'IRC: 86-1983, Geometric design of urban roads in plain terrains' ${ }^{[12]}$, for a cycle volume of 50 to 250 cycles per hour ( 2 way), the minimum width of the cycle track should be $3 \mathrm{~m}$ (dual lane).

- Due to space constraint, cycle track of $2.0 \mathrm{~m}$ width with dual lanes is adopted.

\section{Parking}

- The places where the ratio of 4-wheelers is less, parking facility for 2-wheelers shall be made. So, from "Tanishq in D.B. road" to "Kovai pazhamudir Nilayam in D.B. road" 2-wheeler parking is feasible.

- The places where the ratio of 4 -wheelers to 2 -wheelers is more, parking facilities for four wheelers can be provided. So, from Int. of D.B. Rd. and West Ramalingam Rd. to Int. of West Arunachalam Rd and D.B. road - 4-wheeler parking is feasible (especially cars).

- Also, there is parking done near bus stops, near Int. of D.B. $\mathrm{Rd}$ and T.V. Swamy Rd - which is not advisable.

- Parallel parking for cars is the most efficient parking layout in terms of number of vehicles relative to the area occupied. Also, the same parking space can be used for 2-wheeler parking.

- Recommended minimum dimensions (as per 'Urban street design guidelines - Pune') includes car parking of $2 \mathrm{~m} \times 5$ $\mathrm{m}$ (parallel parking), 2-wheeler parking of $1 \mathrm{~m} \times 2 \mathrm{~m}$ and cycle parking of $1 \mathrm{~m} \times 2 \mathrm{~m}$.

- Hence a parking space width of $2 \mathrm{~m}$ has been adopted in the design.

\section{$\underline{\text { Right of way }}$}

- RoW for D.B. road: $21 \mathrm{~m}$ (Arterial road)

- Average existing land width (Carriageway + Footpath etc.) $=17 \mathrm{~m}$.

- Land width required to meet RoW: $2 \mathrm{~m}$ on either side of the road.

- With existing land features and the commercial centres on either side of D.B. road, it is impossible to extend $2 \mathrm{~m}$ on either side.

- So, the RoW can be fixed as $18 \mathrm{~m}$ such that this can be accommodated on any one side or $0.5 \mathrm{~m}$ each on either side 
of D.B. road.

\section{Carriage way}

- Recommended lane width for single lane is $3.5 \mathrm{~m}$.

- Since the carriage way width reduces along its path, necessary measures like traffic calming measures are to be taken to reduce the speed of the vehicle so that it would not cause accidents to pedestrians.

- The average existing carriage way width is $10 \mathrm{~m}$. The carriage way width varies as per availability of RoW.
- The average existing carriage way width is $10 \mathrm{~m}$. The carriage way width varies as per availability of RoW.

- The adopted carriageway is $6.5 \mathrm{~m}$ (dual lane) and it is maintained constant.

Figure 18 and 19 describes the proposed section of roads where bus stops are provided and where on-street parking is adopted through AutoCAD drawing.

The cumulative numeric details of the proposed road sections (Refer figure 18 and 19) are provided in table 8.

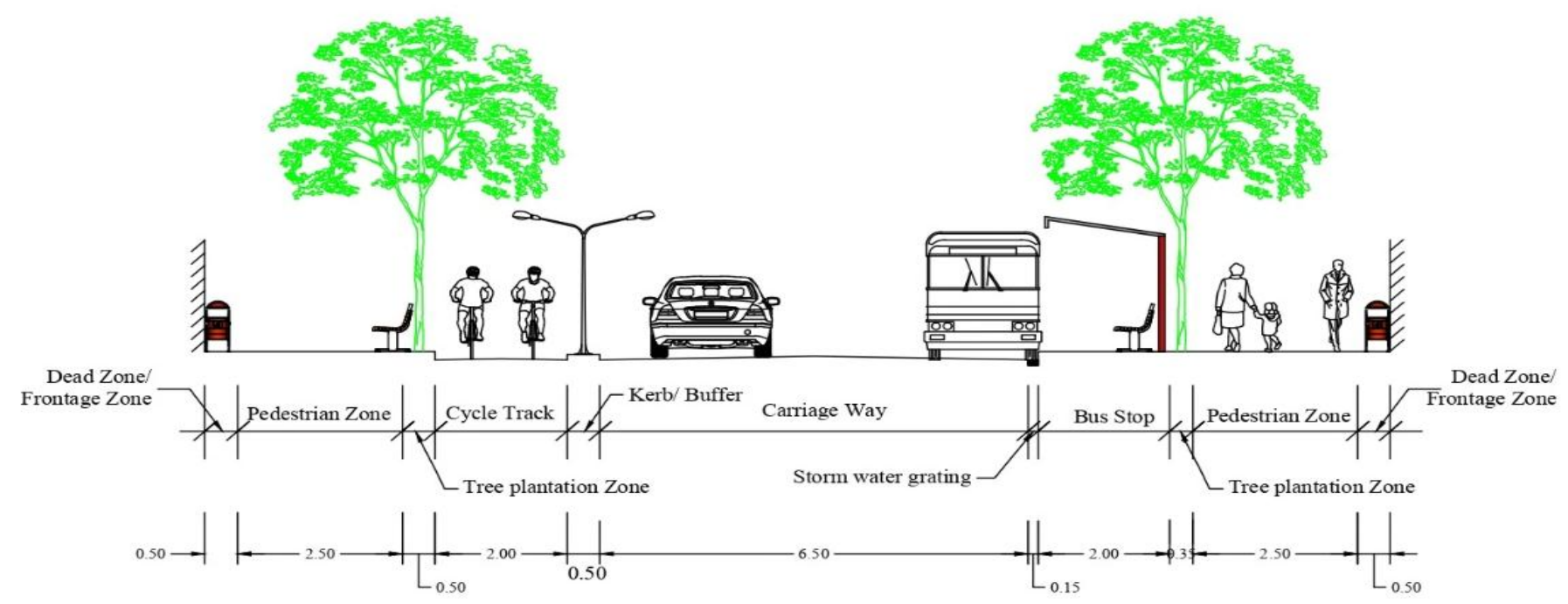

PROPOSED SECTION OF DB ROAD, RS PURAM COIMBATORE

(Section where Bus stops are provided)

ALL DIMENSIONS ARE IN METRES UNLESS SPECIFIED

Figure 18: The proposed section of road where bus stops are to be provided.

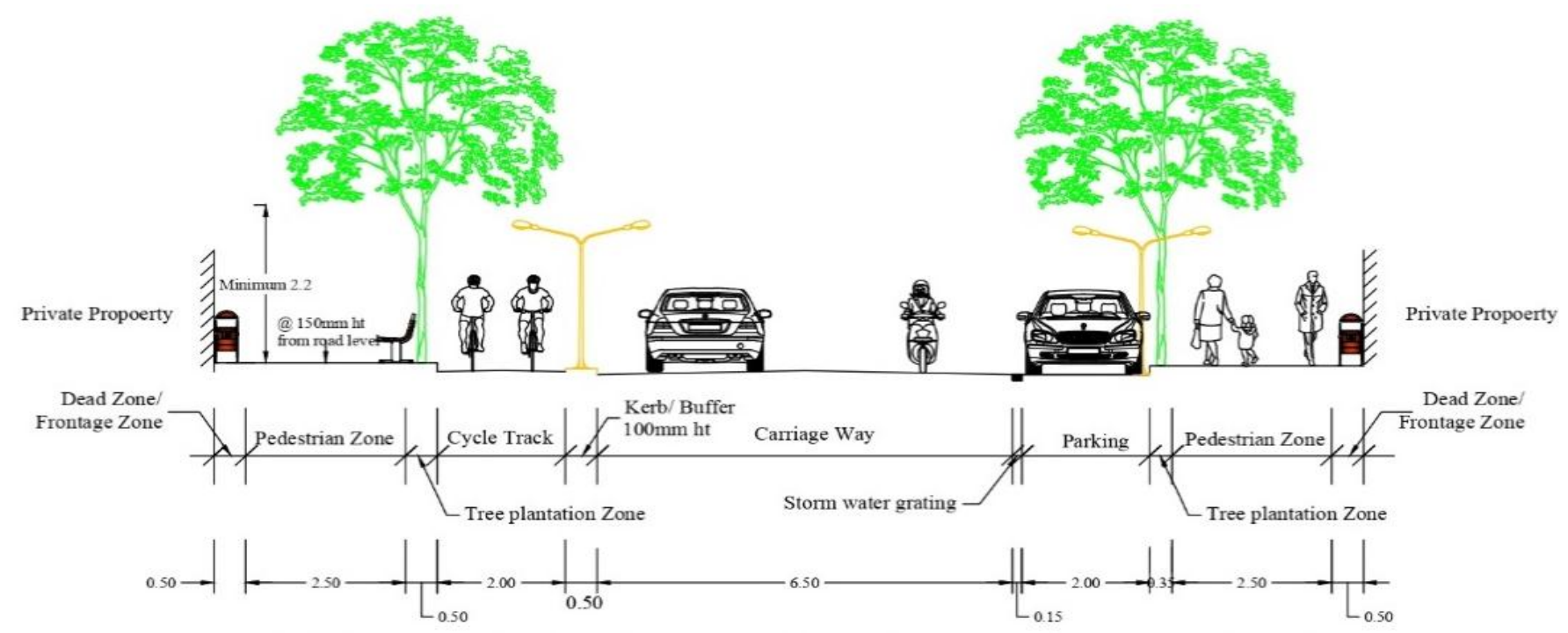

PROPOSED SECTION OF DB ROAD, RS PURAM COIMBATORE

(Section where On-street parking is provided)

ALL DIMENSIONS ARE IN METRES, UNLESS SPECIFIED

Figure 19: The proposed section of road where on-street parking is provided. 
Table 8: Shows the details of the proposed sections of the D.B. road

\begin{tabular}{|c|c|c|c|}
\hline \multicolumn{2}{|c|}{ Street elements } & \multirow{2}{*}{\begin{tabular}{|l|} 
Existing \\
$2 \mathrm{~m}$
\end{tabular}} & \multirow{2}{*}{\begin{tabular}{|l|} 
Proposed \\
$0.5 \mathrm{~m}$
\end{tabular}} \\
\hline \multirow[t]{3}{*}{ Footpath } & $\begin{array}{l}\text { Frontage } \\
\text { zone }\end{array}$ & & \\
\hline & $\begin{array}{l}\text { Pedestrian } \\
\text { zone }\end{array}$ & & $2.5 \mathrm{~m}$ \\
\hline & \begin{tabular}{|l|} 
Plantation \\
zone
\end{tabular} & & $0.5 \mathrm{~m}$ \\
\hline \multicolumn{2}{|c|}{ Cycle track } & NA & $2 \mathrm{~m}$ \\
\hline \multicolumn{2}{|c|}{ Total road width } & $17 \mathrm{~m}$ to $18 \mathrm{~m}$ & $18 \mathrm{~m}$ \\
\hline \multicolumn{2}{|c|}{ Carriage way width } & $10 \mathrm{~m}$ (Varies) & $6.5 \mathrm{~m}$ (Constant) \\
\hline \multicolumn{2}{|c|}{ Marked parking slots } & NA & Available \\
\hline \multicolumn{2}{|c|}{$\begin{array}{l}\text { Separate parking for } 2 \text { - } \\
\text { \& 4-wheelers }\end{array}$} & NA & Available \\
\hline \multicolumn{2}{|c|}{ Bi-cycle parking } & NA & $\begin{array}{l}10 \text { bi-cycle slots } \\
\text { for every } 100 \mathrm{~m} \\
\text { stretch of the road }\end{array}$ \\
\hline
\end{tabular}

\section{DISCUSSION:}

As per observation on D.B. road, R.S. Puram, Coimbatore, pedestrian flow of 1359 persons per hour is observed in both the directions. The footpath width is provided as $2.5 \mathrm{~m}$ (pedestrian zone). Apart from the width, a dead width of $0.5 \mathrm{~m}$ and plantation zone of $0.5 \mathrm{~m}$ are also being provided.

In order to enhance the quality of pedestrian facilities, the following suggestion can be looked for;

- Comfort, continuity and safety are the governing criteria for the design of pedestrian facilities.

- Streets are often designed from the centreline giving first priority for the motorized vehicles. Whatever the space left over after creating the carriageway would be used for the pedestrian facility. Also, the light poles, electricity boxes would often create a hindrance to the movement of the passengers. Even with adequate width of footpath, there may be frequent discontinuities for entry to the private property. High kerb heights and steps make the footpath unfit for elderly persons and persons with disabilities. Many-a-times, poor footpaths are conveniently used as parking for 2-wheelers.

- Unlike the above said cases, the footpath designed shall be universally accessible. It must be convenient and safe for the elderly and the persons with disabilities to move.

- The clear distance of the footpath must be maintained such that the electricity boxes etc, in the path of pedestrians must be removed suitable.

As per the 'Code of Practice for Urban Roads (Part 2)' [9], the provisions for bollards are discussed;

- Instead of providing frequent discontinuities, footpath must be continuously provided. The height of the footpath shall be maintained the same. To provide access to the private properties, vehicle ramps shall be provided at the gradient of 1:6.

- Bollards must be suitable spaced so that the vehicles would not enter into the footpath or any other pedestrian facility. Recommendation for the location and dimensions of bollards are tabulated in table 11. The designed intersection has regular bollards of $650 \mathrm{~mm}$ height and $700 \mathrm{~mm}$ spacing on footpath and it shall be deemed to comply with the minimum requirement as per table 9 .

Table 9: Shows the recommendation for location and dimensions of bollards

\begin{tabular}{|l|c|l|l|}
\hline Location & $\begin{array}{l}\text { Gap } \\
\text { Spacing }\end{array}$ & Height & Remarks \\
\hline On footpath & $0.6 \mathrm{~m}$ & $0.5 \mathrm{~m}-0.7 \mathrm{~m}$ & $\begin{array}{l}\text { Less gap and height } \\
\text { are intended to } \\
\text { restrict the vehicle } \\
\text { entry and facilitate } \\
\text { pedestrians carrying } \\
\text { luggage (One gap of } \\
\text { 0.9 m should be left } \\
\text { for wheel chair } \\
\text { users). }\end{array}$ \\
\hline $\begin{array}{l}\text { On bi-cycle } \\
\text { tracks }\end{array}$ & $0.7 \mathrm{~m}$ & $0.2 \mathrm{~m}-0.4 \mathrm{~m}$ & $\begin{array}{l}\text { This will not } \\
\text { facilitate cyclists } \\
\text { carrying milk cans } \\
\text { or cylinders hung on } \\
\text { sides, but will } \\
\text { restrict the entry of } \\
\text { 2-wheelers into bi- } \\
\text { cycle tracks. }\end{array}$ \\
\hline $\begin{array}{l}\text { On streets / } \\
\text { Refuge } \\
\text { islands etc. }\end{array}$ & $0.8 \mathrm{~m}$ & $0.9 \mathrm{~m}$ & $\begin{array}{l}\text { The height can be } \\
\text { increased to 1.1 min } \\
\text { order to make the } \\
\text { bollard clearly } \\
\text { visible. }\end{array}$ \\
\hline
\end{tabular}

- The minimum width required for the two-way movement of persons in wheel chair is $1800 \mathrm{~mm}$. This is the width of pedestrian zone. In the street designed, the width of pedestrian zone provided is $2500 \mathrm{~mm}$, which is more than the above requirement. Although the existing width of 2000 $\mathrm{mm}$ is acceptable as per above criteria, but the footpath discontinues abruptly at the intersections and other places, which makes it unfit for the free movement of persons with disability. The footpath designed however is continuous even at intersections and other places, which makes it unfit for the free movement of persons with disability. The footpath designed however is continuous even at intersections. Hence the footpath designed is accessible for the persons with disabilities.

- Persons with vision impairment need guidance in using a pedestrianised area, especially if the footway crosses larger open spaces where the usual guidance given by the edge of the footway or building base is not available, or when pedestrians need guidance around obstacles. A continuous 
tactile guide (guiding \&warning tile) in the direction of pedestrian travel, which has a different texture to the rest of the footway, can provide this guidance. A distance of 600 $\mathrm{mm}-800 \mathrm{~mm}$ to be maintained from the edge of footpath / boundary wall / any obstruction.

- A height of about $5 \mathrm{~mm}$ for the raised part of the surface is sufficient for almost all persons with vision impairment to detect, without causing too much discomfort for other pedestrians.

- Tactile paving must be maintained to ensure that the profile does not erode away - vitrified non-glazed tactile pavers are preferable.

- Tactile tiles should have a colour (preferably canary yellow), which contrasts with the surrounding surface.

- Tactile paving should be minimum $300 \mathrm{~mm}$ wide so that someone cannot miss it by stepping over it. A typical tactile paver is as shown in figure. Also, the patterns used for various types of intersections are shown in figure.

- For footpaths, anti-skid tile / matt finished tiles are preferred, which will ensure safety of pedestrians.

\section{Provision of NMT facilities (Bi-cycle tracks)}

- Good cycle tracks are continuous and provide for uninterrupted movement. They are physically separated from the main carriage way to ensure both comfort and safety, and are protected from encroachment by parked vehicles, pedestrians and street vendors.

- Bi-cycles offer low-cost, pollution-free mobility and occupy only a fifth as much driving and parking space as automobiles. Often cyclists are not considered in the street design process. Even they are considered, the cycle track is uneven and not in good condition. Lack of enforcement also makes the cycle track as place for parking, vending etc.

- Provision of well-constructed separate pathway / track for cycles will increase the use of NMT and hence eventually reduce the usage of personalized vehicle. Thereby, this will reduce the vehicular emissions and congestion on roads.

- This lane, for NMT shall be constructed using smooth finish cement concrete or asphalt in order to ensure low maintenance and smooth riding surface. Light colours are preferred because dark colours trap more heat and increases the heat in the surroundings.

- Bi-cycles are a very desirable and affordable private feeder service to MRTS / BRTS stations. To encourage their usage therefore - safe and secure cycle parking options shall be provided. Secure cycle parking shall be provided at all MRTS / BRTS stations. The bi-cycle parking may be of two types - long stay parking and short stay parking.

- Long stay parking: Bi-cycle parking lots shall be enclosed, ticketed (like car-parking lots) and shaded from weather. Bi-cycle parking lots can be combined with ticket counter booths, local police booths, bi-cycle service stations or shared areas within private building complexes.

- Short stay parking: shall be open to view and close to entrances of destinations.

- As a suggestion 10 cycle parking slots for every $100 \mathrm{~m}$ of street edge can be provided.

\section{Provision of tree planting and landscaping}

- Trees planted shall not interfere or obstruct the clear pedestrian zone that is provided. It should be upright and branched above $2.4 \mathrm{~m}$ so that it will not affect the visibility of pedestrians.

- Trees shall be placed such that it does not obstruct the street lighting, signage and traffic signals.

- Tree pits can be provided for all trees as individually or connected.

- The trees shall be pruned from the bottom so that safety devices, signage and traffic signals are clearly visible.

- Native trees that grow in a columnar fashion shall be preferred so that the irrigation requirement and space requirement are minimum. Trees like Eucalyptus, Australian Acacia, Lantana, Lucena, Mast tree, Ashoka tree must be avoided.

- At locations where there are existing trees on edge of carriage way, they can be highlighted by chevron road markings, cat's eye and reflective posts so that they are made visible at night. If possible, they can be shifted to other place if such a measure will not affect their lives.

\section{Provision of on-street parking}

A well maintained on-street parking is clearly designated, managed, charged and restricted in volume, enabling access to nearby properties without causing obstruction.

As per ITDP ${ }^{[13]}$ following provisions are established;

- On-street parking is convenient and easy for the people to access the areas. But poorly managed on-street parking may obstruct the passage of pedestrians or may occupy considerable space in the carriage way, thereby reducing the usable width of the carriage way.

- For 4-wheelers, parallel parking is more desirable since the space occupied is less. Also, the width of the parking area is such that the same width can be used for parallel parking of 4-wheelers and $90^{\circ}$ or angular parking of 2-wheelers.

- The area which to be designated as 2-wheeler parking or 4wheeler parking is determined based on the number of 4wheeler to number of 2-wheeler ratio. The stretches where this ratio is more, 4-wheeler parking can be permitted and where this ratio is less, 2 -wheeler parking can be permitted.

- Horizontal distance of $0.5 \mathrm{~m}$ is being provided on the edge of the parking so that the overhangs do not obstruct the pedestrians.

- Parking shall not be allowed for a minimum of $50 \mathrm{~m}$ on all arms near the intersection. This space can be utilized for creating additional lane so that the queuing vehicles on the motorized traffic lane can be accommodated.

- Parking bays shall not be continuous. They shall be interrupted at maximum $22 \mathrm{~m}$ to provide bulb-out spaces for street furniture, vending zones, etc.

For managing on-street parking, the following measures are suggested:

- Demarcating clearly between parking and no parking zones

- Marking parking slots

- Enforcement of strict parking rules 
- Pricing the parking area to manage demand. Charge can be levied on high occupancy streets. The price for parking can be based on location, time of the day, vehicle size, parking duration.

- Instead of creating park and ride facilities in urban areas, creating dense network of walking, cycling and public transport facilities.

\section{Provision of traffic calming measures}

Traffic calming consists of engineering and other measures put in place on road to slow down the vehicles on that road. This will reduce the accidents for pedestrians and cyclists. This can be broadly achieved by creating full or partial physical barriers, change in alignment, variation in surface levels and materials and with visual barriers.

As per IRC:35-1197 ${ }^{[14]}$ and IRC: $67-2012^{[15]}$, there are two main principles for speed reducing measures;

\section{Visual measure (includes speed limit signs, painted strips and plants)}

\section{Physical measure}

- Some of the examples of the above mentioned are lane narrowing, speed breakers / speed humps, circular humps, trapezoidal humps, Sinusoidal humps, Speed tables, raised crossing, raised intersections, textured pavements, roundabouts, chicanes, chokers, realigned intersections, alternative parking bays etc.

- As per observation, the number of pedestrian crossing D.B. road near the intersection of west Arokiasamy road with D.B. road is high and hence traffic calming measure shall be planned to safe guard the pedestrians.

- From the intersection of west Arokiasamy road till the intersection of east Arokiasamy road (where the pedestrian crossing is high) raised crossing shall be provided with ramps provided at slope of 1:6 at D.B. road, junction of west and east Arokiasamy road with D.B. road. Also, bollards of $650 \mathrm{~mm}$ height and $700 \mathrm{~mm}$ spacing shall be provided at the edges of pedestrian and cycle tracks. The height of the crossing table shall be at $150 \mathrm{~mm}$ from the proposed road level. The surface of crossing shall be provided with paver blocks that are anti-skid and of different colour that of the road. This will give a warning to the riders to slow down their vehicles.

\section{Provision of signage}

- As per study, it was observed that there was no pedestrian crossing signage provided at the intersection of D.B. road and T.V. Swamy road.

- Similarly, at the intersection of west Arokiasamy road and D.B. road, where the traffic calming measure has been proposed, signage for pedestrian crossing shall be placed.

- The observation on the parking of vehicles on D.B. road resulted that there no signage indicating the specific use of the parking space, whether it is for 2-wheeler or 4-wheeler, the same shall be placed. On the other hand, near the intersection of D.B. road and T.V. Swamy road and all other minor intersections, where the parking has to be prohibited, corresponding signage shall be placed.

- On pedestrian footpath and cycle tracks 'pedestrian only' and 'cycles only' signage shall be placed.

- The posts and supports for signage shall be either GI pipes conforming to IS 1239, rectangular hollow sections conforming to IS 4923 or square hollow sections conforming to IS 3589. For the signs that are having an area up to $0.9 \mathrm{~m}^{2}$, it shall be mounted on a single post, and for greater area two or more posts shall be provided. The material used for sign post may be of MS, RCC(M25) or GI.

\section{CONCLUSION}

Now-a-days, there is a catastrophic increase in the use of personalized vehicles. People do not prefer going by cycle or by public transport, their condition may be one among many reasons. Due to this there is an increased emission level. The way to divert the people's focus towards the usage of nonmotorized vehicles is to improve the existing features and to provide new means whichever is unavailable. The main principle behind street design is to convert the existing road that is vehicle friendly to roads that are pedestrian friendly.

The term smart city refers to a city that makes the life of its citizens easy, safe and simple. It comprises of excellent urban planning. It has a good traffic planning and management that makes the travel of each mode easier. There are many existing smart cities in the world. In India the concept of smart city is slowly emerging. During the phase 1 of smart cities mission, by Government of India, 100 smart cities have been announced. Among them Coimbatore also finds a place.

With constant growth in population and being listed in the phase 1 smart city project by Government of India, it is inevitable to manage the traffic in the city. It is also indispensable that the vehicular emissions increase as population increase. So, in order to reduce this emission, large number of non-motorised mode of transport must be encouraged. To encourage those adequate facilities must be made by the local authority so that it will make the people themselves self-driven to use the non-motorised mode of transport. For this the existing streets are to be altered to house the amenities for pedestrians and cyclists.

\section{ACKNOWLEDGEMENT}

We take immense pleasure and feel happy in expressing our humble gratitude and thankfulness to our guide, Dr. K. Elangovan, Professor, Department of Civil Engineering, PSG College of Technology for being the constant source of inspiration for us and guiding us through the project.

The contributions were done by the following members, G. Gowtham, B. Pranav Srinidhi, S. Siva Venkatesh Anand, R. Jeevanantham and A. Iyyanar.

Last but not the least; we thank our parents and God for the 
International Journal of Applied Engineering Research ISSN 0973-4562 Volume 16, Number 5 (2021) pp. $423-440$

(C) Research India Publications. https://dx.doi.org/10.37622/IJAER/16.5.2021.423-440

moral support given to us.

\section{REFERENCES:}

[1] Gowtham G, Pranav Srinidhi B, Siva Venkatesh Anand S, Jeevanantham R, Iyyanar A, Tharunvel S V, "Traffic planning for Coimbatore smart city using GIS", an unpublished B.E project, Department of Civil Engineering, PSG College of Technology, Coimbatore, India, 2018.

[2] IRC: 93 - 1985, “Guidelines on design and installation of road traffic signals".

[3] “Coimbatore Street Design and Management Policy" by ITDP.

[4] “A presentation for second anniversary celebrations of Bhubaneshwar Smart City” - India Smart City Mission

[5] Gupta Das, Sudhasil, Sarkar. P.K, "Effect of bus stops on capacity of urban roads - A case study of Delhi urban area". International Conference on Transportation Systems Planning and Operation, IIT Madras, Chennai, India, 2004.

[6] Muror, Tudor, Bertolini, Luca. "Planning for pedestrians: A way out of traffic congestion". Procedia - Social and Behavioural Sciences, 2013, pp. 600 - 608.

[7] Gonzalo-Orden, Heńan. Rojo, Marta. Acebo, Heriberto Perez. Linares, Alaitz. "Traffic calming measures and their effect on variation of speed". Transportation Research Procedia, 2016, pp. 349 - 356.

[8] Advani, Mukti, Parida, Purnima, Manoranjan. "Methodology for evaluating walking facilities based on the types of obstructions on footpath of Indian roads". Transportation Research Procedia, 2017, pp. 5282 5290.

[9] “Code of Practice for Urban Roads (Part 2)" - by the TRIPP.

[10] Khanna. S.K, Justo. C.E.G, Veeraragavan. A, "Highway engineering", Nem Chand and Bros, $10^{\text {th }}$ edition, Roorkee, 2015.

[11] Kadiyali. L.R, "Traffic Engineering and Transportation Planning", Khanna publishers, New Delhi, 2013.

[12] IRC: 86 - 1983, “Geometric standards for urban roads in plains".

[13] "Parking Basics" - by ITDP.

[14] IRC: 35 - 1997, "Code of practice for road markings".

[15] IRC: 67 - 2012, “Code of practice for road signs". 